\title{
Mechanistic comparison of Bacillus subtilis 6S-1 and 6S-2 RNAs-commonalities and differences
}

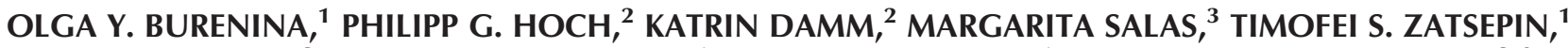 \\ MARCUS LECHNER, ${ }^{2}$ TATIANA S. ORETSKAYA, ${ }^{1}$ ELENA A. KUBAREVA, ${ }^{1}$ and ROLAND K. HARTMANN ${ }^{2,4}$ \\ ${ }^{1}$ Chemistry Department and A.N. Belozersky Institute of Physico-Chemical Biology, M.V. Lomonosov Moscow State University, \\ 119991 Moscow, Russia \\ ${ }^{2}$ Institut für Pharmazeutische Chemie, Philipps-Universität Marburg, 35037 Marburg, Germany \\ ${ }^{3}$ Centro de Biología Molecular "Severo Ochoa" (CSIC-UAM), Universidad Autónoma de Madrid, Cantoblanco, 28049 Madrid, Spain
}

\begin{abstract}
Bacterial 6S RNAs bind to the housekeeping RNA polymerase ( $\sigma^{\mathrm{A}}-\mathrm{RNAP}$ in Bacillus subtilis) to regulate transcription in a growth phase-dependent manner. $B$. subtilis expresses two 6S RNAs, 6S-1 and 6S-2 RNA, with different expression profiles. We show in vitro that 6S-2 RNA shares hallmark features with 6S-1 RNA: Both (1) are able to serve as templates for pRNA transcription; (2) bind with comparable affinity to $\sigma^{\mathrm{A}}$-RNAP; $(3)$ are able to specifically inhibit transcription from DNA promoters, and (4) can form stable 6S RNA:pRNA hybrid structures that (5) abolish binding to $\sigma^{\mathrm{A}}$-RNAP. However, pRNAs of equal length dissociate faster from 6S-2 than 6S-1 RNA, owing to the higher A,U-content of 6S-2 pRNAs. This could have two mechanistic implications: (1) Short 6S-2 pRNAs (<10 nt) dissociate faster instead of being elongated to longer pRNAs, which could make it more difficult for 6S-2 RNA-stalled RNAP molecules to escape from the sequestration; and (2) relative to 6S-1 RNA, 6S-2 pRNAs of equal length will dissociate more rapidly from 6S-2 RNA after RNAP release, which could affect pRNA turnover or the kinetics of 6S-2 RNA binding to a new RNAP molecule. As 6S-2 pRNAs have not yet been detected in vivo, we considered that cellular RNAP release from 6S-2 RNA might occur via 6S-1 RNA displacing 6S-2 RNA from the enzyme, either in the absence of pRNA transcription or upon synthesis of very short 6S-2 pRNAs ( 5-mers, which would escape detection by deep sequencing). However, binding competition experiments argued against these possibilities.
\end{abstract}

Keywords: 6S-1 RNA; bsrA; 6S-2 RNA; bsrB; pRNA transcripts; affinity for $\sigma^{\text {A }}$-RNAP; 6S RNA:pRNA hybrid stability; 6S-2 RNA release from RNAP

\section{INTRODUCTION}

6S RNA is a bacteria-specific noncoding RNA (ncRNA) that primarily binds to RNA polymerase (RNAP) holoenzymes containing the housekeeping $\sigma$ factor, $\sigma^{70}$ in Escherichia coli and $\sigma^{\mathrm{A}}$ in Bacillus subtilis (Wassarman and Storz 2000; Willkomm and Hartmann 2005; Wassarman 2007). Depending on the particular expression profile of a 6S RNA, the RNA sequesters a substantial fraction of the housekeeping RNAP holoenzyme, which then becomes unavailable for transcriptional activity at DNA promoters (Wassarman 2007). This block can be relieved when RNAP synthesizes so-called product RNAs (pRNAs) of a certain length utilizing 6S RNA itself as a transcription template, which then triggers the release of RNAP (Wassarman and Saecker 2006; Gildehaus et al. 2007; Beckmann et al. 2011).

\footnotetext{
${ }^{4}$ Corresponding author

E-mail roland.hartmann@staff.uni-marburg.de

Article published online ahead of print. Article and publication date are at http://www.rnajournal.org/cgi/doi/10.1261/rna.042077.113.
}

Unlike E. coli and many other bacteria encoding a single 6S RNA, the B. subtilis genome encodes two 6S RNA homologs. At their discovery, the genes for the two ncRNAs were termed $b s r A$ and $b s r B$ (Ando et al. 2002; Suzuma et al. 2002), but their nature as 6S RNAs was only unveiled in a later study by the Wassarman group (Trotochaud and Wassarman 2005). Both RNAs were shown to coimmunoprecipitate with the $\sigma^{\mathrm{A}}$ housekeeping RNAP holoenzyme using antibodies against $\sigma^{\mathrm{A}}$ or the core subunit a (Trotochaud and Wassarman 2005). Recent investigations provided evidence that 6S1 RNA displays all of the hallmarks of a canonical 6S RNA: (1) It reaches its highest steady-state levels during late exponential/early stationary phase (Barrick et al. 2005; Beckmann et al. 2011); (2) it serves as an RNA template for massive pRNA transcription, particularly during outgrowth from stationary phase upon resupply of nutrients, as inferred from

\footnotetext{
(c) 2014 Burenina et al. This article is distributed exclusively by the RNA Society for the first 12 months after the full-issue publication date (see http://rnajournal.cshlp.org/site/misc/terms.xhtml). After 12 months, it is available under a Creative Commons License (Attribution-NonCommercial 3.0 Unported), as described at http://creativecommons.org/licenses/by$\mathrm{nc} / 3.0 /$.
} 
deep sequencing (dRNA-seq) (Beckmann et al. 2011) and Northern blot analyses (Beckmann et al. 2011; Cavanagh et al. 2012); and (3) longer pRNAs (12- to 14-mers), whose fraction increases during outgrowth from stationary phase (Beckmann et al. 2011), form a stable duplex with 6S-1 RNA and induce a structural rearrangement in 6S-1 RNA. The rearranged 6S-1 RNA:pRNA complexes lose their affinity for $\sigma^{\mathrm{A}}$-RNAP to liberate $\sigma^{\mathrm{A}}$-RNAP for transcription at DNA promoters during the newly initiated exponential phase. 6S-1 RNA levels then decrease upon entering a new exponential growth phase and increase again when nutrients become scarce and cells enter another stationary growth phase (Beckmann et al. 2012).

The function of B. subtilis 6S-2 RNA is currently a matter of debate. The RNA was observed to reach highest steadystate levels between early and mid-exponential phase and to decrease toward stationary phase (Ando et al. 2002; Barrick et al. 2005; Beckmann et al. 2011). Deviating from these observations, B. subtilis 6S-2 RNA levels were also reported to remain fairly constant in exponential and stationary phase (Trotochaud and Wassarman 2005; Cavanagh et al. 2012).

We have demonstrated in vitro that the $\sigma^{\mathrm{A}}$-RNAP holoenzyme is able to synthesize pRNAs on 6S-2 RNA as a template (Beckmann et al. 2011). So far, deep sequencing analyses have not provided evidence for the synthesis of 6S-2 RNA-derived pRNAs in vivo (Irnov et al. 2010; Beckmann et al. 2011). We hypothesized that $6 S-2$ pRNAs may be rapidly degraded in vivo or substantial 6S-2 pRNA synthesis may occur during yet-to-be-defined adaptations to certain environmental or stress conditions (Beckmann et al. 2011). It was recently shown that pRNA synthesis by $\sigma^{\mathrm{A}}$-RNAP is most efficient with GTP as the initiating nucleotide (Cabrera-Ostertag et al. 2013), in line with the finding that a B. subtilis strain expressing a chromosomal 6S-1 RNA mutant initiating pRNA transcription with ATP instead of GTP showed reduced pRNA synthesis in B. subtilis (Beckmann et al. 2011). Since 6S-2 pRNAs are initiated with ATP (Beckmann et al. 2011) and $6 \mathrm{~S}-1$ pRNAs with GTP, it has been posited that $6 \mathrm{~S}-2$ RNA may not direct pRNA synthesis under physiological conditions (Cabrera-Ostertag et al. 2013), raising the question of how the sequestration of RNAP by 6S-2 RNA can be overcome.

Here, we investigated the mechanistic properties of $B . s u b$ tilis 6S-2 RNA in direct comparison with those of 6S-1 RNA. In vitro at a concentration of $200 \mu \mathrm{M}$ each NTP, the most abundant pRNA transcripts synthesized by $\sigma^{\mathrm{A}}$-RNAP are 13- to 16-mers in the case of 6S-2 RNA and 14-mers with 6S-1 RNA. Since competition experiments between DNA promoters and 6S RNA have only been done for E. coli (Wassarman and Saecker 2006; Gildehaus et al. 2007) and not for B. subtilis, we have performed first experiments in this direction. We show that both 6S RNAs bind to $\sigma^{\mathrm{A}}$ RNAP with very similar affinity, and both RNAs are able to inhibit transcription at model DNA promoters in vitro. Transcription by $\sigma^{\mathrm{A}}$-RNAP on 6S-2 RNA as a template results in 6S-2:pRNA hybrids. Their formation reduces the amount of complex with RNAP, but this reduction appears to be less efficient for 6S-2 RNA relative to 6S-1 RNA. An explanation is that pRNAs of equal length dissociate faster from $6 \mathrm{~S}-2$ than 6S-1 RNA, thus favoring rebinding of 6S-2 RNA to RNAP within the time frame of the applied experimental conditions. Annealing of longer synthetic 6S-2 pRNAs (20 nt) reduced the rate of pRNA dissociation to a negligible extent, comparable to the stabiltiy of 6S-1 RNA:pRNA 14-mer complexes. We also demonstrate that 6S-2 RNA with a bound pRNA is unable to bind to $\sigma^{\mathrm{A}}$-RNAP. Overall, pRNA synthesis from 6S-2 RNA is more sensitive to lowering the NTP concentration than that from 6S-1 RNA as a template, in line with a previous study (Cabrera-Ostertag et al. 2013). We further tested the possibility that 6S-1 RNA may be able to displace 6S-2 RNA from its complex with $\sigma^{\mathrm{A}}$-RNAP.

\section{RESULTS}

\section{S-1 and 6S-2 RNA structures}

The solution 2D structure of B. subtilis 6S-1 RNA has been determined with good confidence by probing experiments (Beckmann et al. 2012). The solution structure of 6S-2 RNA is less clear and RNAfold or mfold predictions for 6S2 RNA are, in contrast to 6S-1 RNA, highly ambiguous (see Supplemental Fig. S1). To improve the confidence of 6S-2 RNA structure prediction, we calculated a consensus secondary structure based on a sequence/structure alignment of closely related homologs to B. subtilis 6S-2 RNA from other bacteria of the Firmicutes branch found in the RFAM database. For comparison, the same was done for 6S-1 RNA (Fig. 1A). The predicted 6S-2 RNA consensus secondary structure (Fig. 1B) has all of the hallmarks of a typical $6 \mathrm{~S}$ RNA (Barrick et al. 2005; Willkomm and Hartmann 2005). Likewise, the in vitro-determined start site for pRNA transcription on 6S-2 RNA as a template (Beckmann et al. 2011) is located in the "central bulge" region, as for 6S-1 RNA (Fig. 1A,B). According to the 6S-2 RNA consensus prediction, the central bulge region closes with three consecutive G-C bp (nt 55-57/124-126) (Fig. 1B). When those 3 bp are constrained in the individual folding prediction for $B$. subtilis 6S-2 RNA, the structure shown in Supplemental Figure S1C is calculated as the minimum free energy structure (MFE) by RNAfold or mfold (the free energy being 7\% less optimal than that of the unconstrained MFE structure) (Supplemental Fig. S1B). The structure shown in Supplemental Figure S1C is basically consistent with the $2 \mathrm{D}$ structure originally proposed (Trotochaud and Wassarman 2005), except for some weak base-pairing interactions in the central bulge that may form transiently.

\section{pRNA transcription pattern for $6 \mathrm{~S}-1$ versus $6 \mathrm{~S}-2$ RNA}

As a next step, the pattern of pRNA transcription by the B. subtilis $\sigma^{\mathrm{A}}$-RNAP at increasing $6 \mathrm{~S}-1$ or $6 \mathrm{~S}-2$ RNA 

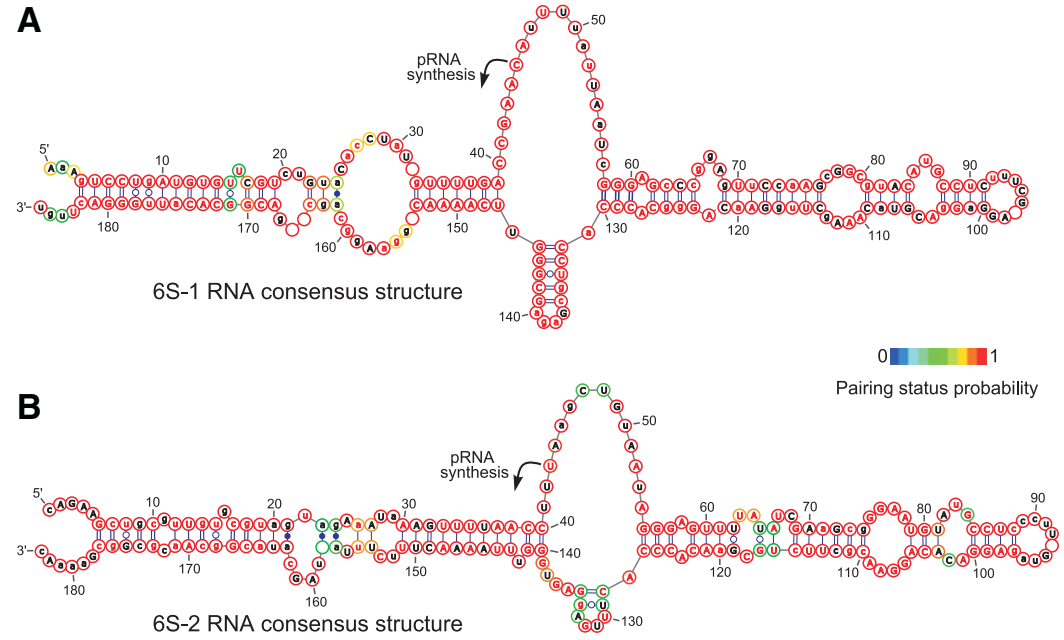

FIGURE 1. Consensus secondary structures of $(A) 14$ different $6 \mathrm{~S}-1$ and $(B) 16$ different $6 \mathrm{~S}-2$ RNAs according to mlocarna (Will et al. 2007) and RNAalifold (Bernhart et al. 2008) using default parameters. The 6S-1 and 6S-2 RNA species selected for the prediction are derived from Firmicutes, for which two 6S RNAs were identified in their genomes, one falling into the 6S-1 and one into the 6S-2 RNA cluster (for further details, see text and Supplemental Fig. S1). The black arrows depict the experimentally determined starting points for pRNA transcription in B. subtilis (Beckmann et al. 2011). The minimum free energy of the 6S-1 RNA consensus structure is $-95.08 \mathrm{kcal} / \mathrm{mol}$ and that of $6 \mathrm{~S}-2 \mathrm{RNA},-92.77 \mathrm{kcal} / \mathrm{mol}$. Circle outline colors depict the probability to be unpaired or paired; residues marked in red have a high probability, i.e., their singlestranded or paired state is well-defined. Letters represent the most frequent base at the corresponding alignment position. Red letters in uppercase indicate highly conserved bases with an occurrence of $>90 \%$, or $>75 \%$ indicated by red lowercase letters. Black letters in uppercase indicate nucleotide identities conserved in $>50 \%$ of the sequences. A small black letter is used for positions with lower or no conservation in the alignment. Empty circles indicate nucleotide insertions in a minor fraction of sequences.

concentrations and in the presence of $200 \mu \mathrm{M}$ each NTP was compared. While 6S-1 RNA gave rise to the 14-mer pRNA as the main "longer" product under these conditions, in line with previous findings (Beckmann et al. 2011, 2012), the prevailing pRNA products were $13-16 \mathrm{nt}$ in length when $6 \mathrm{~S}-2$ RNA served as the template (Fig. 2, lanes 10-14), the 14- and 15 -mers being most prominent. Our findings demonstrate that 6S-2 RNA shares the capacity with 6S-1 RNA to serve as a template for pRNA transcription in vitro. A difference between the two is the broader pRNA length spectrum seen in the case of 6S-2 RNA-derived pRNA transcription (Fig. 2).

\section{Affinity of 6S-1/2 RNAs for B. subtilis $\sigma^{\text {A }}$-RNAP}

An electrophoretic mobility shift assay (EMSA) was employed to study $6 \mathrm{~S}-1 / 2$ RNA affinity for the B. subtilis $\sigma^{\mathrm{A}}$-RNAP. For this purpose, $5^{\prime}{ }_{-}{ }^{32} \mathrm{P}$-labeled $6 \mathrm{~S}-1$ or $6 \mathrm{~S}-2$ RNA was incubated with increasing amounts of $\sigma^{\mathrm{A}}$-RNAP holoenzyme in the absence of NTPs, followed by $7.5 \%$ nondenaturing PAGE analysis (Fig. 3). This revealed similar $K_{\mathrm{d}}$ values for 6S-1 RNA $\left(K_{\mathrm{d}} \approx 100 \mathrm{nM}\right)$ and $6 \mathrm{~S}-2$ RNA $\left(K_{\mathrm{d}} \approx 135 \mathrm{nM}\right)$ (see Fig. 3 ). Approximately $85 \%$ of the $\sigma^{\mathrm{A}}$-RNAP holoenzyme batch used in Figure 3 was capable of 6S RNA binding (Supplemental Fig. S2). We conclude that 6S-1 and 6S-2 RNAs have very similar affinities for the B. subtilis $\sigma^{\mathrm{A}}$-RNAP holoenzyme.

\section{Competition of 6S RNAs with DNA promoters}

Based on studies performed so far only in the Escherichia coli system, an inherent function of 6S RNAs is to compete with DNA promoters for binding to the housekeeping RNAP holoenzyme, $\sigma^{70}$ RNAP in E. coli (Wassarman and Saecker 2006). Thus, an approach to compare 6S-1 and 6S-2 RNA function is inhibition of DNA transcription in the presence of increasing amounts of 6S RNA. For this purpose, we selected two wellstudied $\sigma^{\mathrm{A}}$-dependent $B$. subtilis DNA promoters, the veg promoter, which is constitutively expressed during vegetative growth (Fukushima et al. 2003), and the ribosomal $r r n B$ P1 promoter (Fig. 4A). B. subtilis RNase P RNA was employed as a control RNA for which no specific binding to $\sigma^{\mathrm{A}}$-RNAP was expected. In such competition assays, the DNA promoter and $\sigma^{\mathrm{A}}$-RNAP (each $100 \mathrm{nM}$ ) were pre-incubated with increasing concentrations of $6 \mathrm{~S}-1,6 \mathrm{~S}-2$, or RNase $\mathrm{P}$ RNA $(0.1-2 \mu \mathrm{M})$ before transcription was initiated by addition of NTPs (Fig. 4B,C). Both 6S RNAs showed considerable and comparable inhibition already at $100 \mathrm{nM}$ in reactions with the veg promoter. In contrast, the control RNA (RNase P RNA) had very little effect on transcription, with possibly some nonspecific inhibition at its highest concentration $(2 \mu \mathrm{M})$ (Fig. 4B). A similar outcome was observed for transcription driven by the $\mathrm{rrnB} \mathrm{P} 1$ promoter, although 6S RNA-mediated inhibition effects appeared somewhat weaker (Fig. 4C) than for the veg promoter (Fig. 4B). We additionally analyzed four $B$. subtilis promoters $(r r n O, \arg C, a p p D, \operatorname{csp} B)$ and one B. subtilis phage $\phi 29$ promoter $(C 2 \phi 29)$, which showed similar trends as the veg and $r r n B P 1$ promoters (data not shown). Although we are aware that inhibition in vitro at a few DNA promoters does not allow conclusions about which genes are affected by $6 \mathrm{~S}$ 1/2 RNAs in vivo on a global scale (Cavanagh et al. 2008; Neusser et al. 2010), our findings provide first evidence that 6S-1 and 6S-2 RNAs have comparable capacities to effectively compete with DNA promoters for binding to $\sigma^{\mathrm{A}}$ RNAP, in line with their very similar affinities for the enzyme (Fig. 3).

\section{S-2 pRNA transcription changes 6S-2 RNA structure and decreases affinity for RNAP}

It was shown that pRNA $\sim 14$-mers transcribed by $B$. subtilis $\sigma^{\mathrm{A}}$-RNAP from 6S-1 RNA rearrange the 6S-1 RNA structure 


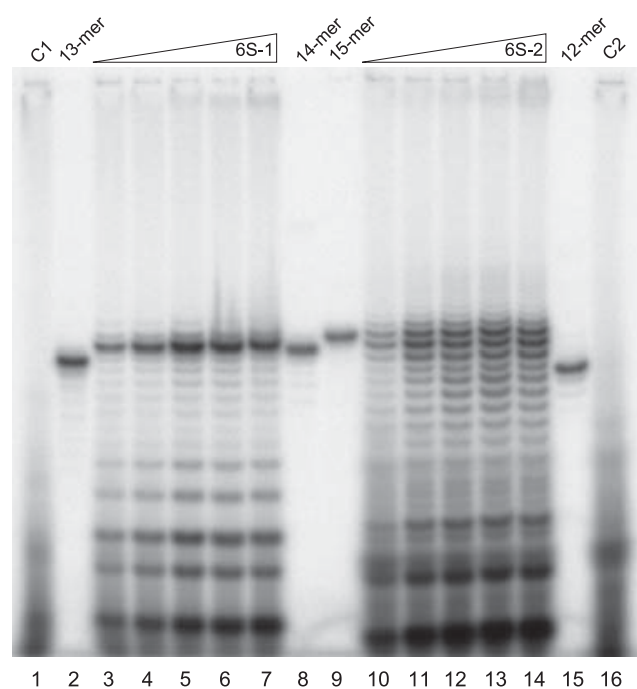

FIGURE 2. In vitro transcription of pRNAs by the B. subtilis $\sigma^{\mathrm{A}}$-RNAP holoenzyme $(1 \mu \mathrm{M})$ using increasing amounts of 6S-1 RNA (lanes 3-7) or 6S-2 RNA (lanes 10-14) as templates. The concentration of 6S RNA was $100 \mathrm{nM}$ (lanes 3,10); $500 \mathrm{nM}$ (lanes 4,11); $1 \mu \mathrm{M}$ (lanes 5,12); $2 \mu \mathrm{M}$ (lanes 6,13), and $5 \mu \mathrm{M}$ (lanes 7,14). Products were analyzed by $25 \%$ denaturing PAGE. As size markers, $5^{\prime}$ - $\left[{ }^{32} \mathrm{P}\right]$-end-labeled chemically synthesized $\mathrm{pRNA}_{6 \mathrm{~S}-1} 13$ - and 14-mers (lanes 2,8) and $\mathrm{pRNA}_{6 \mathrm{~S}-2} 12-$ and 15 -mers (lanes 15,9$)$ were used. $\alpha-\left[{ }^{32} \mathrm{P}\right]$-UTP was added to transcription in lanes 1 and $3-7$, while in lanes $10-14$ and $16, \alpha-\left[{ }^{32} \mathrm{P}\right]$-ATP was used for transcript labeling. Lanes 1 and 16 are negative transcription controls where 6S RNA was omitted. Note that synthetic pRNA oligonucleotides used as size standards and carrying a $5^{\prime}-\left[{ }^{32} \mathrm{P}\right]$-monophosphate may not always comigrate exactly with pRNA transcripts carrying a $5^{\prime}$-triphosphate. For further details, see Materials and Methods.

in cis, which manifests as retarded electrophoretic mobility of 6S-1 RNA in nondenaturing PAA gels. Simultaneously, such stable 6S-1 RNA:pRNA 14-mer complexes lose affinity for $\sigma^{\mathrm{A}}$-RNAP (Beckmann et al. 2012). We thus set out to examine whether 6S-2 RNA shares these mechanistic hallmarks with 6S-1 RNA. After pre-equilibration of ${ }^{32} \mathrm{P}$-labeled $6 \mathrm{~S}-2$ RNA (f.c. $1 \mu \mathrm{M}$ ) and $\sigma^{\mathrm{A}}$-RNAP (f.c. $2 \mu \mathrm{M}$ ), NTPs (f.c. 200 $\mu \mathrm{M}$ each) were added to start pRNA transcription, followed by withdrawal of aliquots at different time points and nondenaturing PAGE analysis. Already at the first time point (1 min), a 6S-2 RNA conformer with retarded mobility appeared (the putative stable 6S-2 RNA:pRNA complex), which correlated with a decrease in the amount of 6S-2 RNA:RNAP complexes (Fig. 5A, cf. lanes 2 and 3). The kinetics of this reaction were essentially complete after $1 \mathrm{~min}$, as later time points (up to $15 \mathrm{~min}$ ) resulted in the same pattern (Fig. $5 \mathrm{~A}$, lanes 3 to 7 ). The gel mobility of the putative $6 \mathrm{~S}-2$ RNA:pRNA complex is the same as that of 6S-2 RNA to which a synthetic ${ }^{32} \mathrm{P}$-labeled pRNA 15 -mer was annealed before native PAGE analysis (Fig. 5B, cf. lanes 13 and 10,11 ), indicating that the 6S-2 RNA band with retarded mobility in Figure 5A, indeed, represents 6S-2 RNA with a newly synthesized pRNA bound to it. Thus, 6S-2 RNA mechanistically behaves as a typical $6 \mathrm{~S}$ RNA under the conditions of our in vitro assay.

\section{A pRNA $_{65-2} 15-$ mer is less effective than a pRNA 65 -1 14-mer in decreasing the fraction of $6 S$ RNAs bound to RNAP}

We then analyzed whether pRNAs of comparable length, either derived from 6S-1 or 6S-2 RNA, are similarly effective in decreasing the fraction of the respective 6S RNA bound to RNAP. In the set of experiments now described, we used synthetic pRNAs that were pre-annealed to 6S RNA. Based on the pRNA transcription profiles illustrated in Figure 2, we initially annealed a 6S-1 RNA-specific 14-mer $\left(\mathrm{pRNA}_{6 \mathrm{~S}-1}\right.$ 14-mer) and a 6S-2 RNA-specific 15-mer ( pRNA $_{6 S-2} 15$ mer) to the cognate ${ }^{32} \mathrm{P}$-labeled 6S RNA (10-fold molar excess of pRNA over 6S RNA), followed by addition of $\sigma^{\mathrm{A}}$ RNAP in the absence of NTPs. Nondenaturing PAGE analysis revealed that both 6S RNAs were entirely shifted into the 6S RNA:pRNA complex after pRNA annealing and before RNAP addition (Fig. 6, lanes 4 and 10). While 6S-1 RNA: pRNA $_{6 S-1}$ 14-mer complexes almost completely abolished 6S-1 RNA binding to RNAP (Fig. 6A, cf. lane 3 and 2; see also Supplemental Fig. S3), reduced but still substantial complexation with RNAP was observed for samples containing
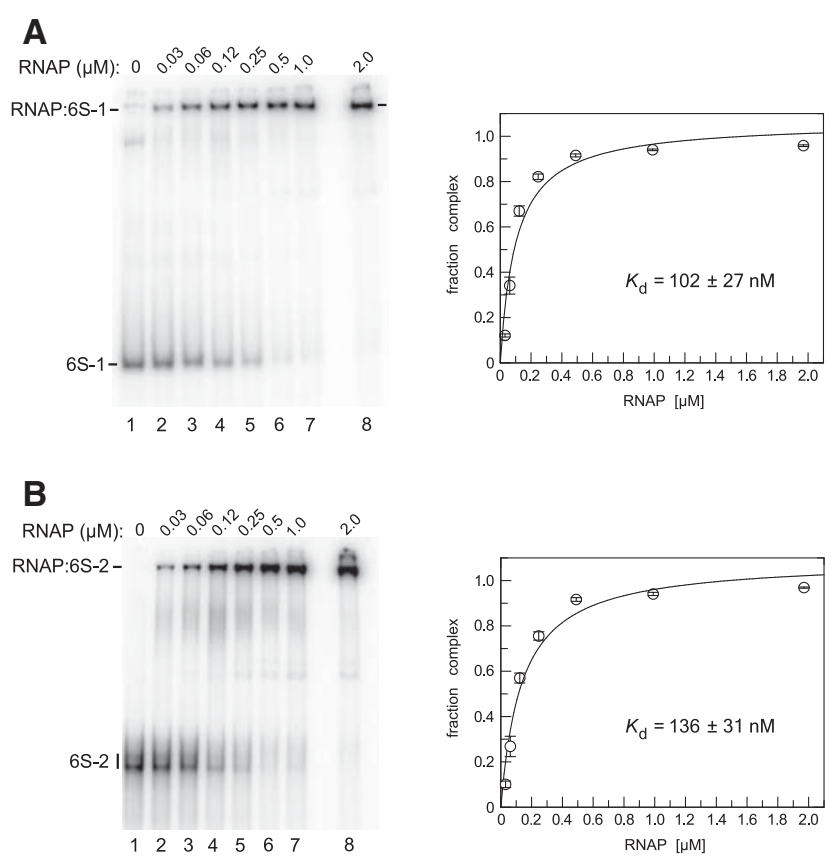

FIGURE 3. Complex formation of trace amounts of radiolabeled $(A)$ 6S-1 RNA or $(B)$ 6S-2 RNA as a function of increasing amounts of $\sigma^{\mathrm{A}}$-RNAP holoenzyme (f.c. indicated above each lane). Lane 1 in each is a control in the absence of $\sigma^{\mathrm{A}}$-RNAP. $K_{\mathrm{d}}$ values indicated in the graphs on the right were obtained by fitting the mean values from six individual experiments each to a binding equation for a single ligand binding site (program Grafit version 3.04, Erithacus Software). Error bars are standard deviations of the mean. For more details, see Materials and Methods. In the gel image of panel A, the RNAP:6S-1 RNA complex (lanes 2-8) indicated by dashes migrates faster than the neighboring band in lane 1 , which likely represents a 6S-1 RNA oligomer. 
A
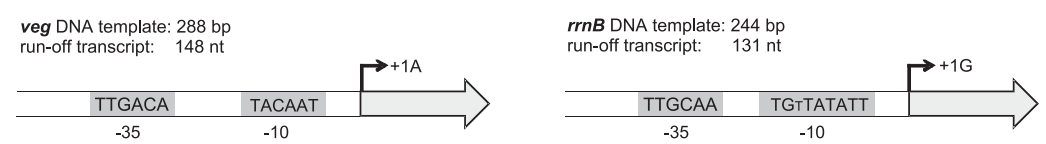

B
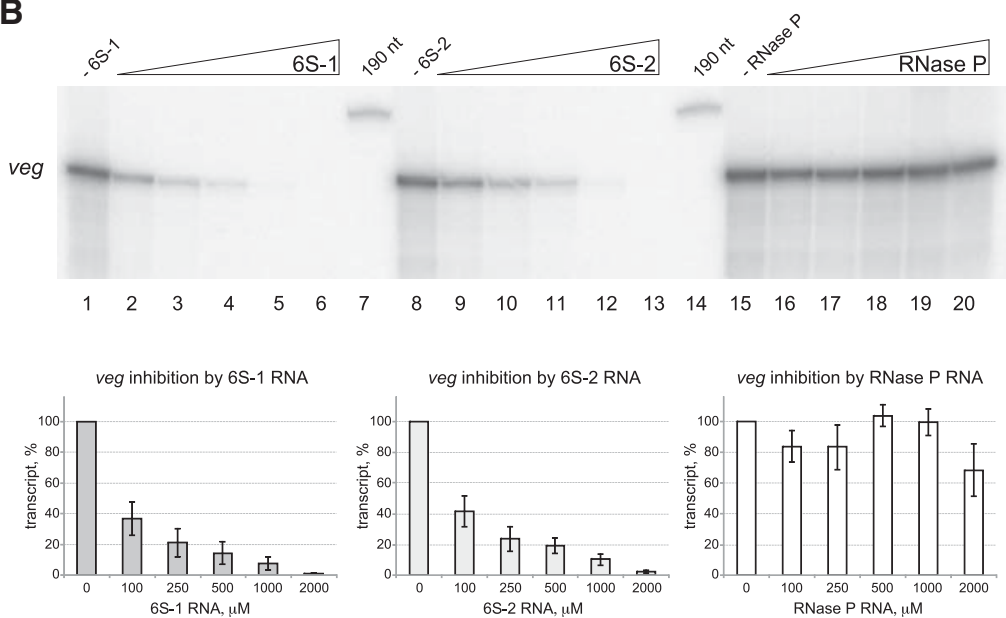

C
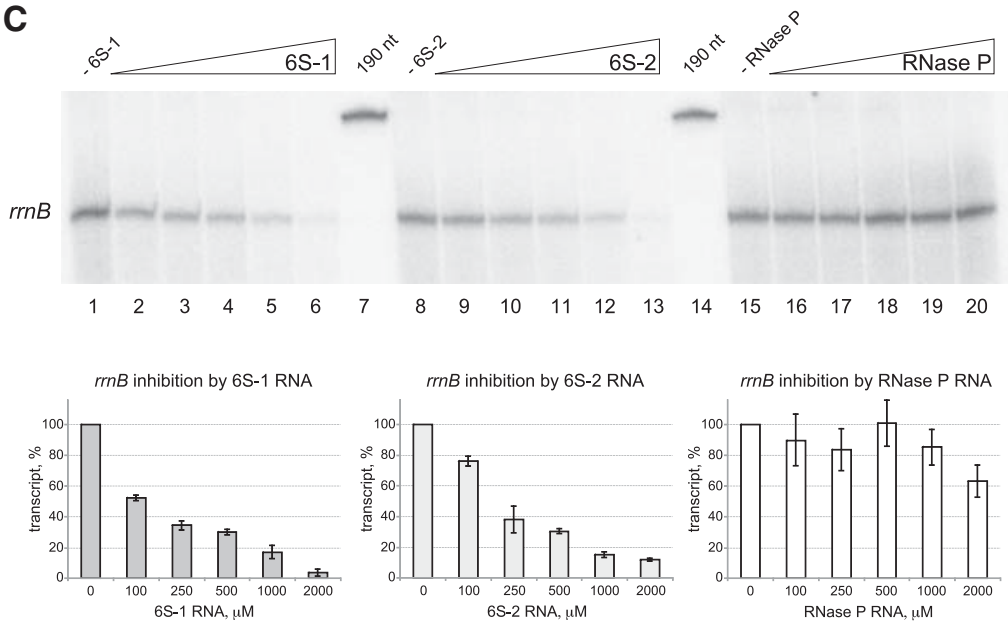

FIGURE 4. 6S-2 RNA as well as 6S-1 RNA inhibit in vitro transcription at the veg and $r r n B$ DNA promoters. (A) Sketch of the two promoter DNA fragments used as transcription templates. The lengths of the T7 run-off transcripts are the theoretical ones based on DNA template complementarity. $(B, C)$ Increasing amounts of 6S-1 RNA (lanes 2-6), 6S-2 RNA (lanes 9-13), or B. subtilis RNase P RNA (RNase P, lanes 16-20, used as a negative control) were added to the $(B)$ veg or $(C)$ $r r n B$ DNA template (f.c. $100 \mathrm{nM}$ ) that had been pre-incubated with the $\sigma^{\mathrm{A}}$-RNAP holoenzyme (f.c. $100 \mathrm{nM}$ ) in $1 \times$ activity buffer. In lanes 1,8 , and 15 , no RNA was added. The final RNA concentrations were as follows: $100 \mathrm{nM}$ (lanes 2,9,16), $250 \mathrm{nM}$ (lanes 3,10,17), $500 \mathrm{nM}$ (lanes $4,11,18$ ), $1 \mu \mathrm{M}$ (lanes 5,12,19), and $2 \mu \mathrm{M}$ (lanes 6,13,20). Transcription was started by adding the NTP mix containing $\alpha-\left[{ }^{32} \mathrm{P}\right]-\mathrm{UTP}$. Products were analyzed by $5 \%$ denaturing PAGE. $5^{\prime}-$ $\left.{ }^{32} \mathrm{P}\right]$-end-labeled 6S-1 RNA (190 nt) served as a size marker (lanes 7 and 14 ). For further details, see Materials and Methods.

6S-2 RNA and the pRNA ${ }_{6 S-2}$ 15-mer (Fig. 6B, cf. lane 9 and 8). This observation suggested that a fraction of $6 \mathrm{~S}-2$ RNA: pRNA 15-mer complexes underwent dissociation during incubation with RNAP, allowing RNAP molecules to capture transiently free $6 \mathrm{~S}-2$ RNAs, which then precludes rebinding of a pRNA.

\section{Thermodynamics of 65 RNA:pRNA hybrids}

A faster dissociation of 6S-2 pRNAs (relative to 6S-1 pRNAs of equal length) was, indeed, suggested by thermodynamic analysis using RNAcofold (Bernhart et al. 2006), which predicted that 6S-2 RNA:pRNA 6 6S-2 20-mer hybrids are roughly isoenergetic to 6S-1 RNA: pRNA $_{6 S-1}$ 14-mer hybrids owing to the A,U-richness of 6S-2 pRNAs (Supplemental Fig. S4).

\section{Analysis of longer pRNA $_{6 \mathrm{~S}-2}$ variants (16- and 20-mer)}

We thus extended our analysis to pRNA $_{6 S-2}$ 16- and 20-mers, using the same setup as in Figure 6. This revealed that the fraction of 6S-2 RNA appearing in the complex with RNAP decreased with increasing pRNA length. With preformed 6S-2 RNA:pRNA 6 -2 20-mer complexes, essentially no residual complex formation with RNAP was observed (Fig. 7A and B, cf. lanes 2 and 3 vs. 9 and 10 vs. 16 and 17). The same trend was seen when we tested $\mathrm{pRNA}_{6 \mathrm{~s}-2} 13-, 14-$, 15-, 16-, and 20-mers next to each other (Supplemental Fig. S5). Note that the pRNA $_{6 S-2} 16$-mer was still among the prevailing pRNA in vitro transcripts, while the 20-mer was among the pRNA transcripts with lower abundance (Fig. 2, lanes 10-14; see also Fig. 9, below).

In a related setup, $5^{\prime}-{ }^{32} \mathrm{P}$-end-labeled pRNA instead of 6S-2 RNA was used. Since pRNA was present in excess over 6S-2 RNA to saturate 6S-2 RNA: pRNA $_{6 S-2}$ hybrid formation, only a subfraction of labeled pRNA appeared in the complex with 6S-2 RNA (Fig. 7A, lanes $6,7,13,14,20$, and 21). Nevertheless, no 6S-2 RNA:pRNA 6 6S-2 hybrids migrating as complexes with RNAP were observed (Fig. 7A, lanes 7, 14, and 21), supporting the notion that 6S RNA: pRNA hybrids have lost the ability to form gel-resolvable complexes with RNAP. Based on these findings, we posit that some 6S-2 RNA:RNAP complex formation seen in lanes 3 and 10 (Fig. 7A,B) is due to significant dissociation of 6S-2 RNA:pRNA 6S-2 $^{2}$ 15/16-mer hybrid duplexes during incubation. The resulting "free" 6S-2 RNAs may then either rebind a pRNA oligonucleotide or bind to 

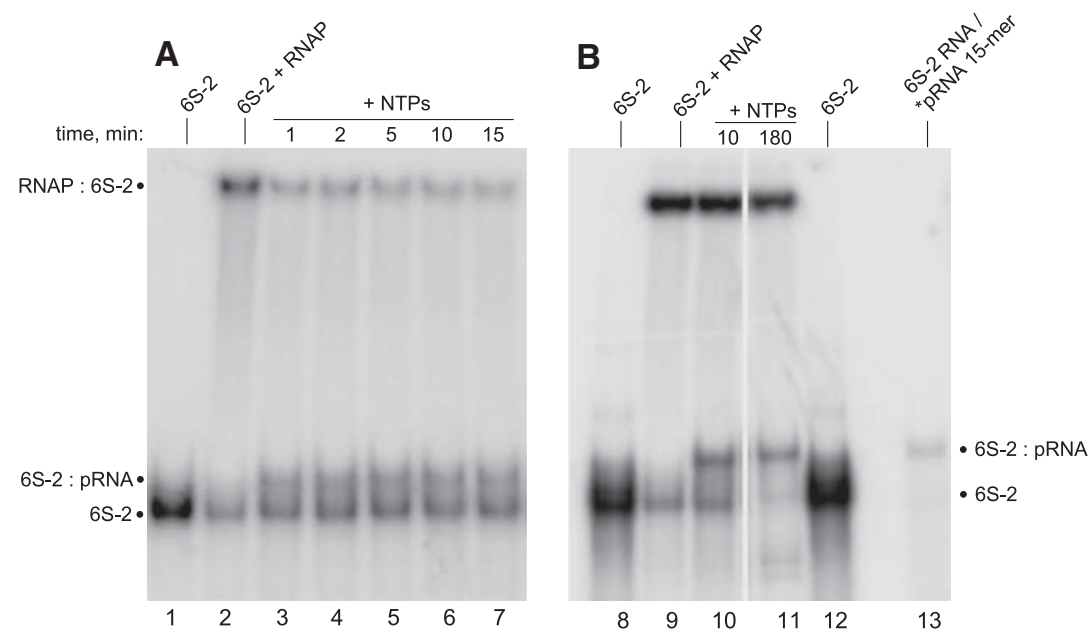

FIGURE 5. (A) 6S-2 RNA-templated pRNA synthesis by B. subtilis $\sigma^{\mathrm{A}}$-RNAP in vitro results in 6S-2 RNA:pRNA hybrids with reduced gel mobility and leads to a reduction in the amount of $\sigma^{\mathrm{A}}$ RNAP:6S-2 RNA complexes. $2.5 \mu \mathrm{M}$ 6S-2 RNA including trace amounts of $5^{\prime}-\left[{ }^{32} \mathrm{P}\right]$-end-labeled 6S-2 RNA ( 10,000 Cherenkov c.p.m. per gel lane) were subjected to the folding and annealing procedure in a volume of $4 \mu \mathrm{L}$ (see Materials and Methods); then $2 \mu \mathrm{L} 5 \times$ activity buffer, $1.06 \mu \mathrm{L}$ $\sigma^{\mathrm{A}}$-RNAP holoenzyme $(8 \mu \mathrm{g} / \mu \mathrm{L})$ were added (except for lane 1$)$, and samples were incubated for $30 \mathrm{~min}$ at $37^{\circ} \mathrm{C}$, followed by addition of $2 \mu \mathrm{L}$ NTP solution (lanes 3-7, f.c. $200 \mu \mathrm{M}$ each NTP) or 2

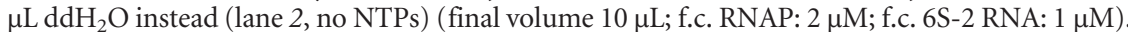
After transcription at $37^{\circ} \mathrm{C}$ for the time period indicated above lanes $3-7$, samples were analyzed by $7.5 \%$ nondenaturing PAGE. Note that the reaction was complete after $1 \mathrm{~min}$. (B) $2.5 \mu \mathrm{M}$ partially labeled 6S-2 RNA (lanes 8-12), or $2.5 \mu \mathrm{M}$ unlabeled 6S-2 RNA together with $25 \mu \mathrm{M}$ partially labeled $\mathrm{pRNA}_{6 \mathrm{~S}-2}$ 15-mer (lane 13) were subjected to the folding and annealing procedure in a volume of $4 \mu \mathrm{L}$ (see Materials and Methods); then, $1 \mu \mathrm{L}$ of heparin solution $(400 \mathrm{ng} / \mu \mathrm{L})$ and 2 $\mu \mathrm{L} 5 \times$ activity buffer were added, and samples were kept at $37^{\circ} \mathrm{C}$; then $1.06 \mu \mathrm{L}$ RNAP holoenzyme $(8 \mu \mathrm{g} / \mu \mathrm{L})$ were added to samples in lanes $9-11$, whereas $\mathrm{ddH}_{2} \mathrm{O}$ was added to the samples of lanes 8,12 , and 13 . Samples were incubated for $30 \mathrm{~min}$ at $37^{\circ} \mathrm{C}$, followed by addition of $2 \mu \mathrm{L}$ nucleotide solution (all four NTPs) to the sample of lane 11 , or $2 \mu \mathrm{L}$ of $\mathrm{ddH}_{2} \mathrm{O}$ to the samples of lanes 8,9,12,13 (final volume $10 \mu \mathrm{L}$; f.c. RNAP: $2 \mu \mathrm{M}$; f.c. $6 \mathrm{~S}-2 \mathrm{RNA}: 1 \mu \mathrm{M}$; f.c. NTPs: $200 \mu \mathrm{M}$ each). After incubation of all samples for $170 \mathrm{~min}$ at $37^{\circ} \mathrm{C}, 2 \mu \mathrm{L}$ NTP solution was also added to the sample of lane 10 , followed by further incubation at $37^{\circ} \mathrm{C}$ for $10 \mathrm{~min}$, after which all samples were loaded onto a $7.5 \%$ nondenaturing PAA gel.

a $\sigma^{\mathrm{A}}$-RNAP molecule, the latter cases appearing as 6S-2 RNA: RNAP complexes in the gel shift assay. In contrast to the 15or 16-mer, the $\mathrm{pRNA}_{6 \mathrm{~S}-2} 20$-mer dissociates from 6S-2 RNA at a much lower rate, such that dissociation of preformed 6S2 RNA:pRNA duplexes becomes negligible within the time frame of the experiment.

To further test this notion, a pRNA transcription inhibition assay was performed. $6 \mathrm{~S}-2$ RNA $(2 \mu \mathrm{M})$ was pre-incubated with a 20 -fold molar excess of synthetic unlabeled pRNA $\mathrm{PS}_{6-2}$ 12-, 13-, 14-, 15-, 16-, or 20-mers (Fig. 8A), or 6S-1 RNA was pre-incubated with a 20 -fold molar excess of synthetic pRNA $_{6 S-1} 12-, 13-$, or 14-mers for comparison (Fig. 8B). Then, $\sigma^{\mathrm{A}}$-RNAP, and finally NTPs, were added to initiate pRNA de novo transcription. Here, the pre-annealed, synthetic pRNA oligonucleotides prevented binding of 6S RNA to RNAP, and solely after their dissociation from 6S RNA, the latter was able to bind to RNAP to serve as a template for de novo pRNA transcription. Only in the presence of the synthetic pRNA $6 \mathrm{~s}-2$ 20-mer (Fig. 8A, lane 5) and pRNA $_{6 S-1} 14$-mer (Fig. 8B, lane 15) pRNA de novo transcription was completely blocked; however, pRNA de novo tran- scription occurred in the presence of shorter synthetic pRNAs, the more the shorter the synthetic pRNA (Fig. 8A, lanes $6-10$, and Fig. 8B, lanes 16,17). Titration experiments with synthetic pRNA $_{6 S-2} 15-$, 16-, and 20-mers and 6S2 RNA as the target confirmed these findings (Supplemental Fig. S6). In conclusion, 6S RNA complexes with shorter pRNAs ( $\leq 16 \mathrm{nt}$ for $6 \mathrm{~S}-2 \mathrm{RNA} ;<14 \mathrm{nt}$ for 6S-1 RNA) (see also Supplemental Fig. S3) underwent measurable dissociation within the experimental time frame.

\section{pRNA synthesis as a function of NTP concentration}

A recent study has reported evidence that pRNA transcription in vitro is less efficient from 6S-2 than 6S-1 RNA, because B. subtilis $\sigma^{\mathrm{A}}$-RNAP prefers a GTP as the initiating nucleotide (iNTP), but $6 \mathrm{~S}-2$ pRNAs initiate with ATP (Cabrera-Ostertag et al. 2013). In addition, the authors saw only weak 6S-2 pRNA transcription at $50 \mu \mathrm{M}$ each NTP, an NTP concentration fourfold lower than the one used here $(200 \mu \mathrm{M})$. We thus analyzed pRNA transcription at different NTP concentrations. In line with the findings of CabreraOstertag et al. (2013), overall pRNA synthesis from 6S-2 RNA decreased more at lower NTP concentrations (20 and 50 $\mu \mathrm{M})$ relative to that from $6 \mathrm{~S}-1$ RNA as template (Fig. 9). At present, it is unclear how this relates to NTP concentrations in vivo. The ATP concentration was recently reported to be $\sim 60 \mu \mathrm{M}$ in exponentially growing $B$. subtilis cells (Meyer et al. 2011), whereas 1-3 mM was reported for intracellular GTP (Ratnayake-Lecamwasam et al. 2001). Yet, the ATP concentration was measured to be three- to fourfold higher than for the other three NTPs (Lopez et al. 1979). For exponentially growing $E$. coli cells, NTP concentrations were determined to be $\sim 4-10 \mathrm{mM}$ for ATP and $\sim 1-5 \mathrm{mM}$ for GTP (Bennett et al. 2009), suggesting that 1-3 mM GTP (Ratnayake-Lecamwasam et al. 2001) in B. subtilis seems more like a realistic estimation. Thus, the intracellular concentration of NTPs available for transcription may well be in the range of $0.2 \mathrm{mM}$ or even higher.

\section{Analysis of 6S-2 RNA displacement from $\sigma^{\mathrm{A}}$-RNAP by $6 \mathrm{~S}-1$ RNA}

Although 6S-2 RNA is basically able to direct pRNA synthesis in vitro, deep sequencing and Northern blot experiments have not provided evidence for 6S-2 RNA-templated pRNA 
A

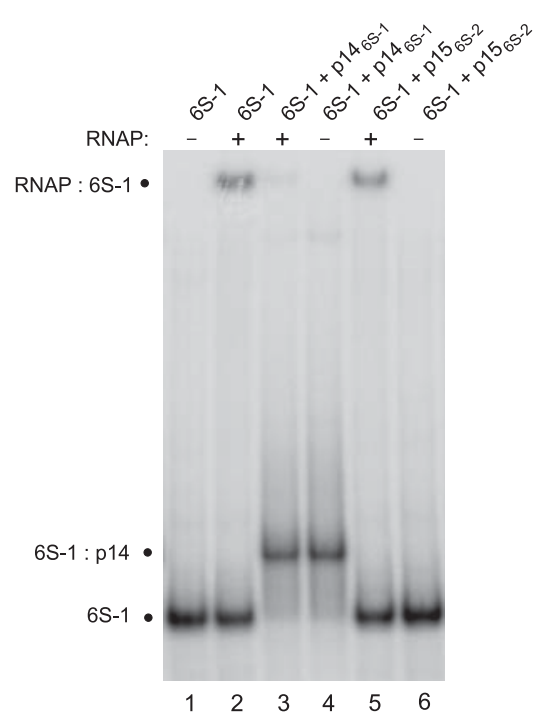

B

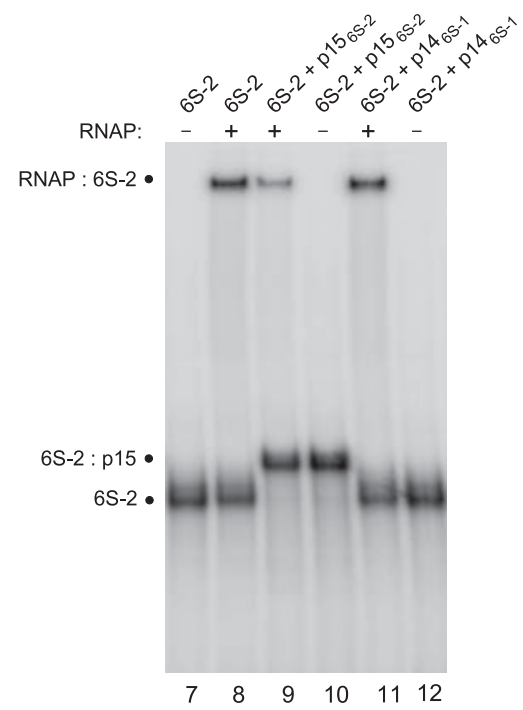

FIGURE 6. A pRNA $6 \mathrm{6S-2} 15$-mer is less effective than a $\mathrm{pRNA}_{6 \mathrm{~S}-1} 14$-mer in promoting release of the cognate 6S RNA from $\sigma^{\mathrm{A}}$-RNAP. (A) $2.5 \mu \mathrm{M}$ 6S-1 RNA including trace amounts of $5^{\prime}-\left[{ }^{32} \mathrm{P}\right]-$ end-labeled 6S-1 RNA were subjected to the folding and annealing procedure, either alone (lanes 1 and 2) or in the presence of $25 \mu \mathrm{M} \mathrm{pRNA}_{6 \mathrm{~S}-1} 14$-mer (lanes 3 and 4) or $25 \mu \mathrm{M} \mathrm{pRNA}_{6 \mathrm{~S}-2} 15$-mer as a noncomplementary control (lanes 5 and 6) in $4 \mu \mathrm{L} 1 \times \mathrm{TE}$ buffer. Then, $2 \mu \mathrm{L} 5 \times$ activity buffer

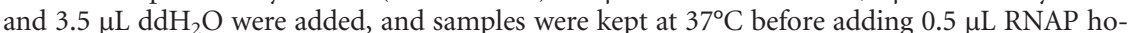
loenzyme $(8 \mu \mathrm{g} / \mu \mathrm{L})$ (lanes $2,3,5)$ or $0.5 \mu \mathrm{L}$ RNAP storage buffer instead (lanes $1,4,6)$, followed by incubation for $30 \mathrm{~min}$ at $37^{\circ} \mathrm{C}$ (f.c. $\sigma^{\mathrm{A}}$-RNAP: $1 \mu \mathrm{M}$, f.c. $6 \mathrm{~S}$ RNA: $1 \mu \mathrm{M}$, f.c. pRNA: $10 \mu \mathrm{M}$ ), gel loading, and 7.5\% nondenaturing PAGE. (B) The analogous experiment with 6S-2 RNA.

synthesis in vivo (Beckmann et al. 2011; Cavanagh et al. 2012). It is thus possible that pRNA synthesis from 6S-2 RNA is negligible, at least under the laboratory growth conditions tested. This raises the question of how $\sigma^{\mathrm{A}}$-RNAP may escape from the block by $6 \mathrm{~S}-2 \mathrm{RNA}$. We tested a simple "6S-1 RNA displaces 6S-2 RNA" model, prompted by the finding that a $B$. subtilis $6 \mathrm{~S}-1$ knockout strain can be rescued from its retarded outgrowth phenotype by resupplying $6 \mathrm{~S}-1$ RNA or by further deleting the 6S-2 RNA gene (Cavanagh et al. 2012). For this purpose, we incubated $0.25 \mu \mathrm{M} \sigma^{\mathrm{A}}$ RNAP (approximately twofold above the $K_{\mathrm{d}}$ for 6S RNA binding) (see Fig. 3) with a fivefold excess of radiolabeled 6S-2 RNA $(1.25 \mu \mathrm{M})$ to allow complex formation, followed by addition of $12.5 \mu \mathrm{M}$ unlabeled 6S-1 RNA (10-fold molar excess over 6S-2 RNA) and incubation for up to $2 \mathrm{~h}$. However, displacement of radioactive 6S-2 RNA from the complex with RNAP was not detectable within this time frame (Fig. 10A).

We then considered the possibility that very short $\mathrm{pRNA}_{6 \mathrm{~S}-2}$ transcripts, which would escape detection by RNA-seq or Northern blotting, might provide sufficient transcriptional and structural dynamics to permit 6S-2 RNA exchange on RNAP by excess $6 \mathrm{~S}-1$ RNA. This was tested by further adding ATP and GTP to the reaction samples of the type shown in Figure 10A, allowing synthesis of pRNA 5-mers (or 6-mers in the case of nontemplated addition of an extra nucleotide) on 6S-2 RNA but essentially preventing any pRNA synthesis on the competitor 6S-1 RNA (pRNA 6 -1 nt 2 and 3 are $U$ residues). Such a setup excludes any complication of the results owing to potential simultaneous pRNA synthesis on 6S-2 RNA and the 6S-1 competitor RNA. In this type of experiment, we saw a trend toward a slight reduction of RNAP:6S-2 RNA complexes after 1-2 $\mathrm{h}$ of incubation (Fig. 10B). However, it is hard to imagine that this rather slow process might mediate efficient dissociation of RNAP:6S-2 RNA complexes in vivo.

\section{DISCUSSION}

\section{S-1 versus 6S-2 RNA- commonalities and differences}

Here, we studied the functional properties of $B$. subtilis $6 \mathrm{~S}-2$ RNA in vitro in comparison with its putative paralog, 6S-1 RNA. Both 6S RNAs share several features in vitro: Both (1) are able to serve as templates for pRNA transcription, (2) bind with comparable affinity to $\sigma^{\mathrm{A}}$ RNAP, (3) are able to specifically inhibit transcription from DNA promoters, (4) yield 6S RNA:pRNA hybrid structures of retarded gel mobility, and (5) with both, formation of stable 6S RNA:pRNA hybrid structures abolishes binding to RNAP.

Despite these commonalities, differences between 6S-1 and 6S-2 RNA were observed as well, which are related to the different G,C-content of the major pRNA species (6S-2 pRNA 13- to 16-mers: $3 \times$ G,C; $6 S-1$ pRNA 14-mer: $6 \times$ G,C). A mechanistic consequence might be that short $6 \mathrm{~S}-2$ pRNAs $(<10 \mathrm{nt})$ dissociate faster instead of being elongated to longer pRNAs, which could make it more difficult for 6S-2 RNA-stalled RNAP molecules to escape from the sequestration (see discussion below). Also, compared with 6S-1 RNA, 6S-2 pRNAs of equal length will dissociate more rapidly from 6S-2 RNA after RNAP release, which could accelerate pRNA decay or favor binding of 6S-2 RNA to a new RNAP molecule.

We recently proposed for 6S-1 RNA that its release from RNAP depends on the interplay of rate constants for pRNA dissociation from 6S-1 RNA $\left(k_{\text {off }}\right)$, for pRNA elongation by $1 \mathrm{nt}\left(k_{\mathrm{pol}}\right)$, and for the structural rearrangement $\left(k_{\mathrm{conf}}\right)$ required for RNAP release (Beckmann et al. 2012). The observation that initiation of $\mathrm{pRNA}_{6 \mathrm{~S}-2}$ synthesis is more reduced for 6S-2 than 6S-1 RNA at lower NTP concentrations $(<200$ $\mu \mathrm{M}$ ) owing to iATP being less favorable than iGTP (CabreraOstertag et al. 2013) requires to further invoke the rate constant for initiation of pRNA synthesis, $k_{\text {init }}$. A lower $k_{\text {init }}$ for 6 S2 RNA is expected to decrease the overall pRNA synthesis rate on the 6S-2 RNA template, while the overall $k_{\text {pol }}$ for pRNA 


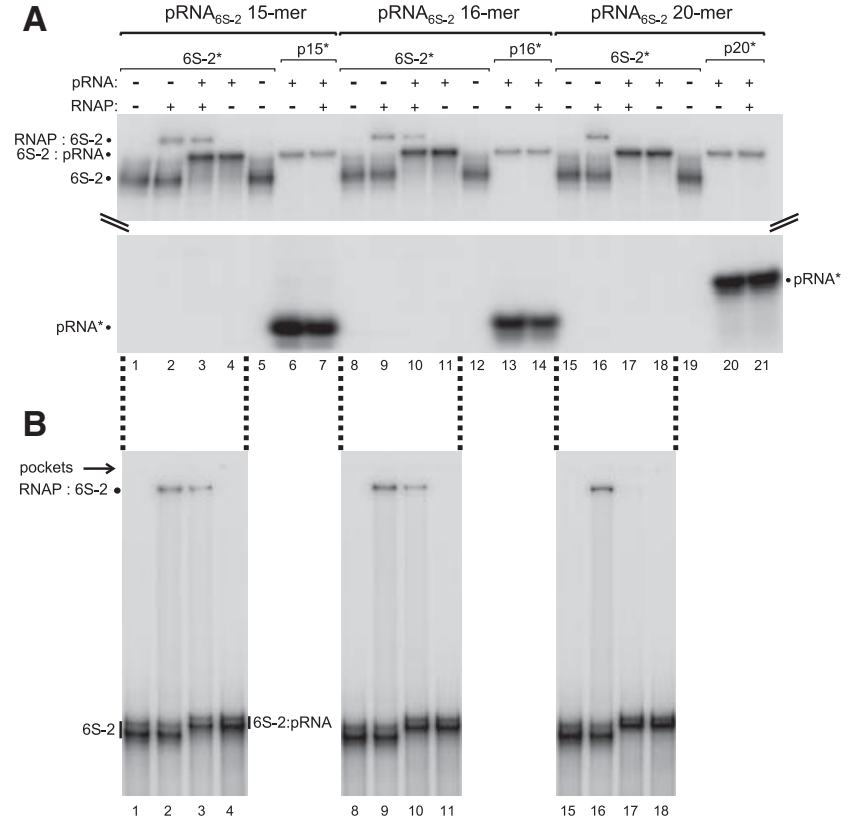

FIGURE 7. Length of $\mathrm{pRNA}_{6 \mathrm{~S}-2}$ affects the release of $\sigma^{\mathrm{A}}$-RNAP from complexes with 6S-2 RNA. (A) $1.67 \mu \mathrm{M}$ 6S-2 RNA were subjected to the folding and annealing procedure, either alone (lanes $1,2,5,8,9,12,15,16,19)$ or in the presence of $16.7 \mu \mathrm{M}$ pRNA $6 \mathrm{~S}-215$-mer (lanes $3,4,6,7$ ) or pRNA $_{6 \mathrm{~S}-2}$ 16-mer (lanes $10,11,13,14$ ) or pRNA $6 \mathrm{S-2}$ 20 -mer (lanes $17,18,20,21$ ) in $6 \mu \mathrm{L} 1 \times \mathrm{TE}$ buffer. In lanes $1-5,8-12$, and $15-19$ the 6S-2 RNA was $5^{\prime}-\left[{ }^{32} \mathrm{P}\right]$-end-labeled, whereas pRNAs were $5^{\prime}-\left[{ }^{32} \mathrm{P}\right]$-end-labeled in lanes $6,7,13,14,20$, and 21 . After annealing, $2 \mu \mathrm{L} 5 \times$ activity buffer and $1.5 \mu \mathrm{L} \mathrm{ddH}_{2} \mathrm{O}$ were added, and samples were kept at $37^{\circ} \mathrm{C}$. Then, $0.5 \mu \mathrm{L}$ RNAP holoenzyme $(8 \mu \mathrm{g} / \mu \mathrm{L})$ was added (lanes $2,3,7,9,10,14,16,17,21$ ) or $0.5 \mu \mathrm{L}$ RNAP storage buffer instead, and samples were incubated for $30 \mathrm{~min}$ at $37^{\circ} \mathrm{C}$, followed by gel loading (f.c. $\sigma^{\mathrm{A}}$-RNAP: $1 \mu \mathrm{M}$, f.c. $6 \mathrm{~S}$ RNA: $1 \mu \mathrm{M}$, f.c. pRNA: $10 \mu \mathrm{M}$ ) and $15 \%$ nondenaturing PAGE analysis. (B) As lanes 1-4, 8-11, and 15-18 in panel $A$ but analyzed by $7.5 \%$ nondenaturing PAGE for improved gel resolution.

elongation (averaged over all pRNA positions starting from addition of $n t+2$ ) may be similar or higher/lower than for the 6S-1 RNA template. The rate constant $k_{\text {off }}$ strongly depends on the length of the nascent pRNA transcript. In the case of 6S-2 RNA, $k_{\text {off }}$ is predicted to be higher for pRNAs of comparable length (e.g., a 6S-2 pRNA 8-mer forms two, a 6S-1 pRNA 8-mer forms five G-C pairs). However, to what extent this predicted faster dissociation rate of $6 \mathrm{~S}-2$ pRNAs takes effect depends on how fast $k_{\mathrm{pol}}$ is at the individual nucleotide addition steps (position $+2,+3,+4$, etc.).

With respect to the function of 6S-2 RNA in vivo, there are two major possibilities: Either (1) the RNA's principle capacity to give rise to pRNA synthesis and to rearrange its structure to release $\sigma^{\mathrm{A}}$-RNAP, as demonstrated in the study presented here, may indicate that 6S-2 RNA exerts this function in vivo under some conditions to be identified; or (2) pRNA synthesis from 6S-2 RNA has lost its functional relevance in vivo, and the blockade of $\sigma^{\mathrm{A}}$-RNAP by $6 \mathrm{~S}-2$ RNA may be lifted by other means. The latter possibility would be consistent with the observation that significant amounts of 6S-2 pRNAs have neither been detected by Northern blotting nor deep sequencing (Beckmann et al. 2011; Cavanagh et al. 2012), and that efficient pRNA synthesis in vitro by $\sigma^{\mathrm{A}}$-RNAP requires a GTP as the initiating nucleotide (Cabrera-Ostertag et al. 2013). According to this scenario, 6S-2 RNA would represent a paralog of 6S-1 RNA that has, on evolutionary time scales, lost its classic biological function only very recently, as in vitro, the RNA still has all the hallmark mechanistic capacities of canonical 6S RNAs.

The latter scenario raises the question about the functional advantage of having a second 6S RNA. The different expression profiles of 6S-1 and 6S-2 RNAs suggest that their functions have, indeed, diversified. It was found in three independent studies (Ando et al. 2002; Barrick et al. 2005; Beckmann et al. 2011) that 6S-2 RNA levels substantially decrease in (extended) stationary phase, indicating that sequestration of RNAP molecules complexed with 6S-2 RNA can be overcome in vivo. The recent finding that a 6S-1 RNA knockout strain displays a retarded outgrowth phenotype, whereas a double knockout of 6S-1/2 does not, suggests that 6S-1 RNA
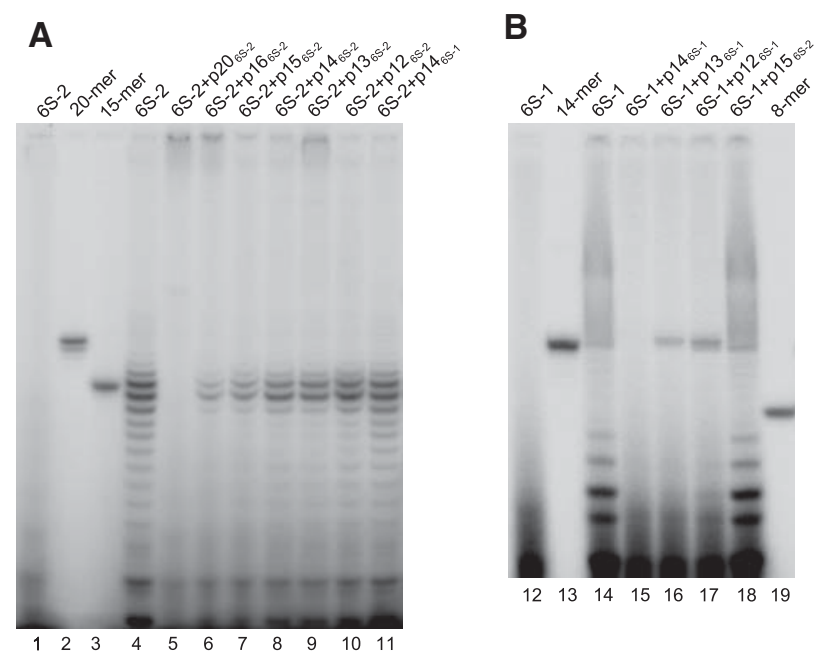

FIGURE 8. The extent of inhibition of pRNA de novo transcription by preformed 6S RNA:pRNA complexes depends on the pRNA length. $(A)$ 6S-2 RNA $(2 \mu \mathrm{M})$ was subjected to the folding and annealing procedure in $5 \mu \mathrm{L}$ of $1 \times \mathrm{TE}$ buffer, either alone (lane 4 ) or in the presence of $40 \mu \mathrm{M}$ pRNA $_{6 \mathrm{~S}-2}$ 20-mer (lane 5), 16-mer (lane 6), 15-mer (lane 7), 14-mer (lane 8), 13-mer (lane 9), 12-mer (lane 10), or pRNA 6 -1 14-mer as control (lane 11, noncomplementary pRNA). After annealing, $0.5 \mu \mathrm{L}$ water, $2 \mu \mathrm{L} 5 \times$ activity buffer, and $0.5 \mu \mathrm{L} \sigma^{\mathrm{A}}$-RNAP $(8 \mu \mathrm{g} / \mu \mathrm{L})$ were added, and reactions were incubated for $30 \mathrm{~min}$ at $37^{\circ} \mathrm{C}$ followed by addition of $2 \mu \mathrm{L}$ of NTP mix (f.c. $200 \mu \mathrm{M}$ each NTP, also containing $\alpha-\left[{ }^{32} \mathrm{P}\right]-\mathrm{ATP}$ ) and further incubation for $30 \mathrm{~min}$ at $37^{\circ} \mathrm{C}$. As size markers, $5^{\prime}-\left[{ }^{32} \mathrm{P}\right]$-end-labeled pRNA 6 S-2 20 -mer (lane 2) and 15-mer (lane 3) were used. (B) 6S-1 RNA $(2 \mu \mathrm{M})$ was subjected to the folding and annealing procedure in 5 $\mu \mathrm{L}$ of $1 \times \mathrm{TE}$ buffer, either alone (lane 14) or in the presence of $40 \mu \mathrm{M}$ pRNA $_{6 S-1}$ 14-mer (lane 15), 13-mer (lane 16), 12-mer (lane 17), or pRNA $_{6 \mathrm{~S}-2} 15$-mer as control (lane 18, noncomplementary pRNA). In vitro transcription by $\sigma^{\mathrm{A}}$-RNAP was performed as in panel $A$, except that the NTP mix contained $\alpha-\left[{ }^{32} \mathrm{P}\right]-\mathrm{UTP}$ instead of $\alpha-\left[{ }^{32} \mathrm{P}\right]-\mathrm{ATP} .5^{\prime}-\left[{ }^{32} \mathrm{P}\right]-$ end-labeled pRNA 6 S-1 14-mer (lane 13) and 8-mer (lane 19) were loaded as size markers. Lanes 1 and 12 are negative transcription controls where 6S RNA was omitted. Transcription products were analyzed by 25\% denaturing PAGE. 
can, by some unknown mechanism, help overcome or prevent the 6S-2 RNA-mediated block of RNAP. Here, we ruled out a simple displacement of $6 \mathrm{~S}-2$ by $6 \mathrm{~S}-1$ RNA owing to different binding affinities for RNAP. A 6S-2 RNA replacement with 6S-1 RNA when RNAP is capable of synthesizing very short 6S-2 pRNAs (5- or 6-mers, in the presence of ATP and GTP only) seems possible, but the slow rate of this process makes its biological relevance questionable. One possibility is that nucleolytic degradation of RNAP-bound 6S-2 RNA can occur and trigger the release of RNAP. Nonetheless, at present we think it is premature to exclude that pRNA synthesis from 6S-2 RNA occurs in vivo at some stage and to such an extent that RNAP molecules sequestered by $6 \mathrm{~S}-2$ RNA are released by this cotranscriptional mechanism.

\section{MATERIALS AND METHODS}

\section{Synthetic RNA oligonucleotides}

6S-1 p12: 5'-GUUCGGUCAAAA-3' (IDT)

6S-1 p13: 5'-GUUCGGUCAAAAC-3' (IDT)

6S-1 p14: 5'-GUUCGGUCAAAACU-3' (Noxxon)

6S-2 p12: 5'-AAAGGUUAAAAC-3' (Noxxon)

6S-2 p13: 5'-AAAGGUUAAAACU-3' (MSU)

6S-2 p14: 5'-AAAGGUUAAAACUU-3' (MSU)

6S-2 p15: 5'-AAAGGUUAAAACUUA-3' (IDT)

6S-2 p16: 5'-AAAGGUUAAAACUUAA-3' (MSU)

6S-2 p20: 5'-AAAGGUUAAAACUUAAUUCA-3' (MSU)

IDT: Integrated DNA Technologies; Noxxon: Noxxon Pharma GmbH; MSU: Lomonosov Moscow State University (for more synthesis details, see Supplemental Material).

\section{T7 transcription of 6S-1 and 6S-2 RNA}

Mature 6S-1 RNA (190 nt; gene bsrA) and 6S-2 RNA (203 nt, gene bsrB) from $B$. subtilis were synthesized by T7 transcription as described (Beckmann et al. 2011). The respective pUC18 derivative plasmids were linearized with HindIII for run-off transcription. The transcription reaction (final volume $0.5 \mathrm{~mL}$ ) contained 80 mM HEPES, pH 8.0, 15 mM DTT, $33 \mathrm{mM} \mathrm{MgCl}_{2}, 1 \mathrm{mM}$ spermidine, $15 \mathrm{mM}$ each NTP, $80 \mu \mathrm{g} / \mathrm{mL}$ template DNA, and 2 units $/ \mathrm{mL}$ pyrophosphatase. The reaction mixture was prewarmed to $37^{\circ} \mathrm{C}$, and guanosine $\left(30 \mathrm{mM}\right.$ stock solution preheated to $\left.75^{\circ} \mathrm{C}\right)$ was added to a final concentration (f.c.) of $9 \mathrm{mM}$ to generate transcripts with $5^{\prime}-\mathrm{OH}$ ends for $5^{\prime}-\left[{ }^{32} \mathrm{P}\right]$-end-labeling. Reactions were started by adding $10 \mu \mathrm{L}$ T7 RNA polymerase (self-prepared, $\sim 40$ units/ $\mu \mathrm{L}$, inferred from direct comparison of transcription efficiency with T7 RNA polymerase from Thermo Scientific, 20 units $/ \mu \mathrm{L}$ ), and incubated for $2 \mathrm{~h}$ at $37^{\circ} \mathrm{C}$. Then, a second aliquot of T7 RNA polymerase $(10 \mu \mathrm{L})$ was added, and the mixture was incubated for another $2 \mathrm{~h}$ at $37^{\circ} \mathrm{C}$. Transcription products were purified by phenol/chloroform extraction and $8 \%$ denaturing PAGE, followed by UV shadowing. Excised product bands were eluted from the gel by diffusion elution (in $1 \mathrm{M} \mathrm{NaOAc}, \mathrm{pH} \sim 5.0$, at $4-7^{\circ} \mathrm{C}$ overnight) followed by ethanol precipitation. RNAs were redissolved in doubledistilled $\mathrm{H}_{2} \mathrm{O}\left(\mathrm{ddH}_{2} \mathrm{O}\right)$ and their concentrations determined by UV spectroscopy.

\section{Preparation of $B$. subtilis $\sigma^{A}$-RNAP holoenzyme}

The B. subtilis $\sigma^{\mathrm{A}}$-RNA polymerase holoenzyme was prepared as described (Sogo et al. 1979). For transcription at DNA promoters, B. subtilis RNAP was prepared from the B. subtilis strain MH5636 as described (Anthony et al. 2000), except that the only chromatographic step performed was affinity-purification using Ni-NTA agarose (Qiagen). This cruder RNAP was highly active in transcription at DNA promoters located on linear PCR fragments.

\section{PCR}

Linear DNA fragments harboring the B. subtilis $r r n B$ and veg promoters ( $\sim 240$ and $\sim 290$ bp, respectively) were amplified from genomic B. subtilis 168 DNA by standard PCR procedures using the following primers (Metabion): Bsub_veg_22Fwd: 5'-d(CATAA TTTACCGAAACTTGCGG)-3'; Bsub_veg_19Rev: 5'-d(CAGAA GGGTACGTCTCAGC)-3'; Bsub_rrnB_31Fwd: 5'-d(GACAAGC TTACACACGCTTTAGAAATCATGG)-3'; Bsub_rrnB_32Rev: 5'-d (GACGTCGACGATCATTTCGTTACTTCTCAATG)-3'. DNA products were then purified by the Wizard SV Gel and PCR Clean-Up System (Promega).

\section{In vitro transcription at DNA promoters}

Transcription reactions (final volume $10 \mu \mathrm{L}$ ) were prepared as follows: 1 pmol of linear DNA fragment (f.c. $100 \mathrm{nM}$ ) was mixed with $2 \mu \mathrm{L} 5 \times$ activity buffer $(0.2 \mathrm{M}$ Tris- $\mathrm{HCl}, \mathrm{pH} 8.0,25 \mathrm{mM}$

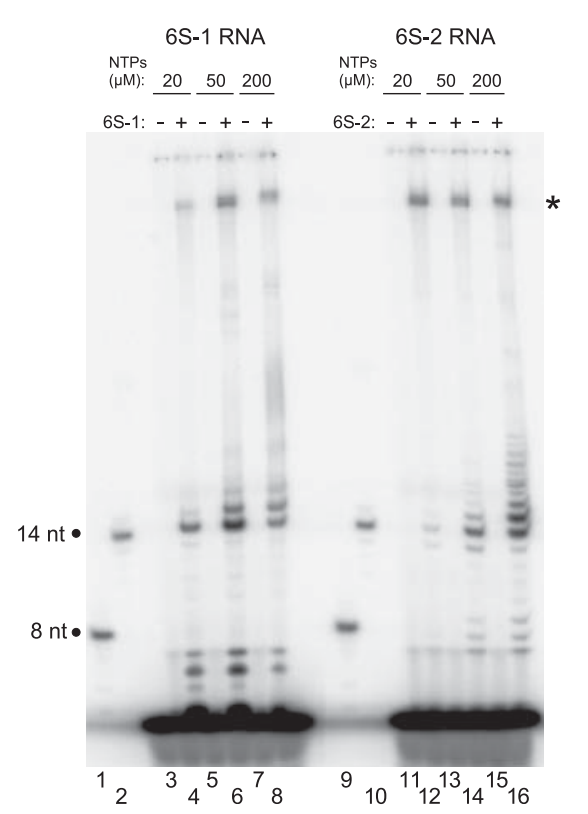

FIGURE 9. 6S-1 or 6S-2 RNA-templated pRNA synthesis at varying NTP concentrations. For details, see Materials and Methods. Lanes 1 , 2, 9, 10: $5^{\prime}-{ }^{32} \mathrm{P}$-labeled RNA length markers mimicking a 6S-1 RNA-derived pRNA 8-mer (5'-GUUCGGUC, lanes 1,9$)$ or a 14 -mer $\left(5^{\prime}\right.$ GUUCGGUCAAAACU, lanes 2,10). Samples were analyzed by denaturing 25\% PAGE. Asterisk at the right margin: These species appear only in the presence of $6 \mathrm{~S}$ RNA; their nature is unknown and currently under investigation. 


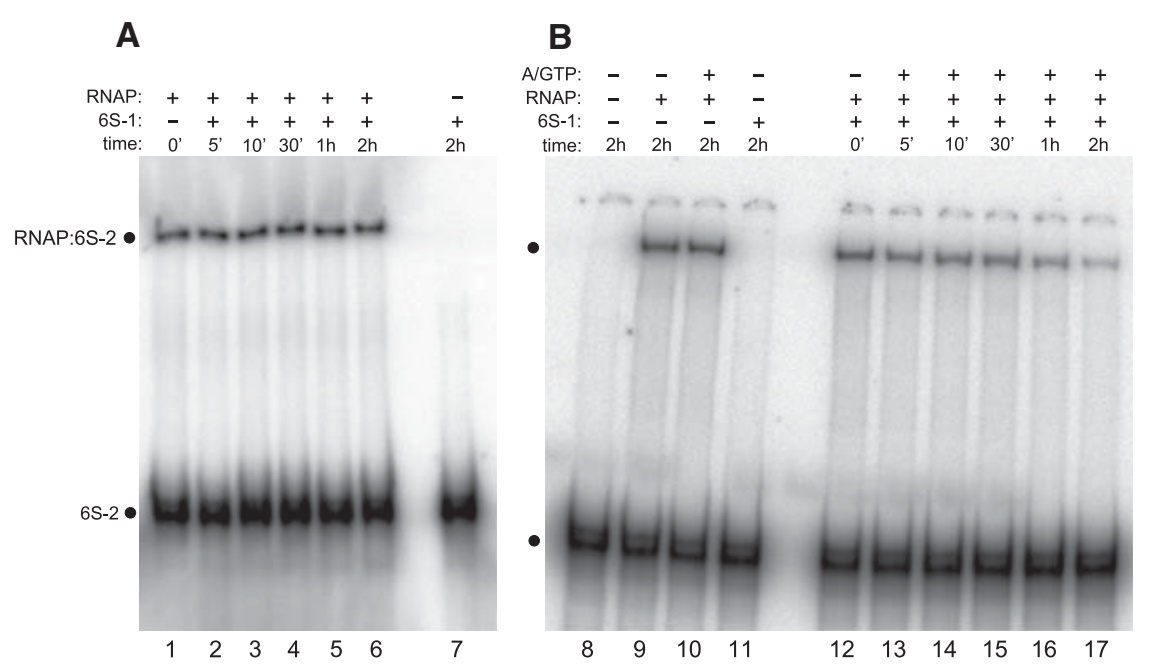

FIGURE 10. (A) Analysis of 6S-2 RNA displacement from $\sigma^{\mathrm{A}}$-RNAP by 6S-1 RNA. $0.25 \mu \mathrm{M} \sigma^{\mathrm{A}}$ RNAP was incubated with a fivefold excess of radiolabeled 6S-2 RNA $(1.25 \mu \mathrm{M})$ in $1 \times$ activity buffer for $15 \mathrm{~min}$ at $37^{\circ} \mathrm{C}$ to allow complex formation. Then, $12.5 \mu \mathrm{M}$ unlabeled $6 \mathrm{~S}-1$ RNA were added, and samples were incubated for $5,10,30,60$, or $120 \mathrm{~min}$ at $37^{\circ} \mathrm{C}$ before loading onto a $7.5 \%$ native PAA. Lane $1: \mathrm{ddH}_{2} \mathrm{O}$ instead of $6 \mathrm{~S}-1$ RNA was added; lane 7 : as lane 6 , but without RNAP (for details, see Materials and Methods). The same result was obtained in two additional independent experiments (data not shown). Also, quantification of phosphorimage signals for free 6S-2 RNA and the complex with RNAP did not reveal any decrease in the proportion of 6S-2 RNA:RNAP complexes over time. (B) Experiment as in panel $A$, but incubation with ATP and GTP (each $200 \mu \mathrm{M}$ ). Lane 8: 6S-2 RNA, no RNAP, no 6S-1 RNA, no NTPs; lane 9: 6S-2 RNA, RNAP, no 6S-1 RNA, no NTPs; lane 10: 6S-2 RNA, RNAP, no 6S-1 RNA, ATP and GTP; lane 11: 6S-2 RNA, no RNAP, 6S-1 RNA, no NTPs; lanes 12-17: as lanes 2-6, but after addition of 6S-1 RNA, samples were incubated for $15 \mathrm{~min}$ at $37^{\circ} \mathrm{C}$, followed by addition of ATP/GTP $\left(\mathrm{ddH}_{2} \mathrm{O}\right.$ instead in lane 12) and incubation for the time period indicated above each lane.

$\mathrm{MgCl}_{2}, 0.8 \mathrm{M} \mathrm{KCl}, 5 \mathrm{mM}$ DTT) supplemented with $0.5 \mu \mathrm{g} / \mu \mathrm{L}$ heparin, $0.6 \mu \mathrm{L} \sigma^{\mathrm{A}}$-RNAP holoenzyme $(0.7 \mu \mathrm{g} / \mu \mathrm{L})$, and $\mathrm{ddH}_{2} \mathrm{O}$ to yield a volume of $6 \mu \mathrm{L}$. This mixture was incubated for $10 \mathrm{~min}$ at $37^{\circ} \mathrm{C}$ to promote DNA:RNAP complex formation. Then, $2 \mu \mathrm{L}$ containing different amounts of 6S-1 RNA, 6S-2 RNA, or B. subtilis RNase P RNA (409 nt, used as a negative control) were added, followed by incubation for another $10 \mathrm{~min}$ at $37^{\circ} \mathrm{C}$ to allow competing RNA: RNAP and DNA:RNAP complexes to equilibrate. Finally, the transcription reaction was started upon addition of $2 \mu \mathrm{L}$ NTP mix (250 $\mu \mathrm{M}$ each ATP, CTP, GTP, and $62.5 \mu \mathrm{M}$ UTP) containing $\alpha-\left[{ }^{32} \mathrm{P}\right]-$ UTP ( 50,000 Cherenkov c.p.m. per gel lane), followed by incubation for $20 \mathrm{~min}$ at $37^{\circ} \mathrm{C}$. The f.c. of $\sigma^{\mathrm{A}}$-RNAP was $\sim 100 \mathrm{nM}$ and that of $6 \mathrm{~S}-1,6 \mathrm{~S}-2$, or RNase P RNA either $0.1,0.2,0.5,1$, or $2 \mu \mathrm{M}$. After transcription, samples were mixed with an equal volume of $2 \times$ denaturing RNA loading buffer (Thermo Scientific), heated for 5 min at $95^{\circ} \mathrm{C}$, followed by immediate transfer onto ice, and then loaded onto a $5 \%$ denaturing PAA gel $(1 \times$ TBE: $89 \mathrm{mM}$ Tris base, $89 \mathrm{mM}$ boric acid, 2 mM EDTA, $\mathrm{pH} \sim 8.3$ ).

\section{Folding and annealing procedure}

In vitro-transcribed $6 \mathrm{~S}-1$ or $6 \mathrm{~S}-2 \mathrm{RNA}$, either alone or in the presence of chemically synthesized pRNA oligonucleotides, were heated to $95^{\circ} \mathrm{C}$ for $5 \mathrm{~min}$ in a volume of $4-8 \mu \mathrm{L} 1 \times$ TE buffer $(10 \mathrm{mM}$ Tris$\mathrm{HCl}, 1 \mathrm{mM}$ EDTA, pH 8.0) and stepwise-cooled (5 min each 80, 70, 60,50 , and $37^{\circ} \mathrm{C}$ ) in a thermocycler (Biometra) to accomplish folding and annealing. Samples also contained trace amounts of either $5^{\prime}$ - $\left[{ }^{32} \mathrm{P}\right]$-labeled $6 \mathrm{~S}-1 / 2$ RNA or pRNA oligonucleotide; RNA concentrations are specified in the respective figure legends.

\section{Analysis of 6S RNA:RNAP complex formation}

Electrophoretic mobility shift assays were conducted as described (Beckmann et al. 2011), using trace amounts of $5^{\prime}-\left[{ }^{32} \mathrm{P}\right]$-labeled $6 S-1$ or $6 S-2$ RNA ( $\sim 5000$ Cherenkov c.p.m. per gel lane) and varying excess amounts of $\sigma^{\mathrm{A}}$-RNAP. After pre-incubation for $30 \mathrm{~min}$ at $37^{\circ} \mathrm{C}$, samples were mixed with an equal volume of $2 \times$ native RNA loading buffer $(0.025 \%$ bromophenol blue [w/v], $0.025 \%$ xylene cyanol blue [w/v], 20\% glycerol), followed by $7.5 \%$ native PAGE ( $1 \times$ TBE). For data analysis and $K_{\mathrm{d}}$ determination, see Beckmann et al. (2011).

\section{S RNA:RNAP gel shifts after pRNA annealing}

To $4 \mu \mathrm{L}$ of $6 \mathrm{~S}-1$ or $6 \mathrm{~S}-2$ RNA that had been subjected to the folding and annealing procedure (see above) in the presence of a complementary pRNA oligonucleotide (controls without pRNA), $2 \mu \mathrm{L}$ of $5 \times$ activity buffer (supplemented with $0.5 \mu \mathrm{g} / \mu \mathrm{L}$ heparin) and

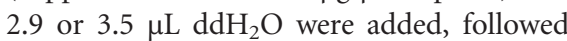
by addition of $1.06 \mu \mathrm{L}$ or $0.5 \mu \mathrm{L}$ of $\sigma^{\mathrm{A}}$-RNAP holoenzyme $(8 \mu \mathrm{g} /$ $\mu \mathrm{L})$ to give a final volume of $10 \mu \mathrm{L}$. Samples were incubated for $30 \mathrm{~min}$ at $37^{\circ} \mathrm{C}$ to promote $6 \mathrm{~S}$ RNA:RNAP complex formation (f.c. $\sigma^{\text {A }}$-RNAP: 2 or $\sim 1 \mu \mathrm{M}$; f.c. 6 S RNA: 1 or $10 \mu \mathrm{M}$ ); finally, samples were mixed with an equal volume of $2 \times$ native RNA loading buffer (or adjusted to $10 \%$ gycerol without dyes, giving the same results) and loaded onto a 7.5\% nondenaturing PAA gel $(1 \times \mathrm{TBE})$.

\section{S RNA:RNAP gel shifts after transcription}

This protocol pertains to the experiment shown in Figure 5. To $4 \mu \mathrm{L}$ 6S-2 RNA $(2.5 \mu \mathrm{M})$ that had been subjected to the folding and annealing procedure, $2 \mu \mathrm{L}$ of $5 \times$ activity buffer (supplemented with $0.5 \mu \mathrm{g} / \mu \mathrm{L}$ heparin), $1 \mu \mathrm{L} \mathrm{ddH}_{2} \mathrm{O}$ and $1.06 \mu \mathrm{L} \sigma^{\mathrm{A}}$-RNAP holoenzyme $(8 \mu \mathrm{g} / \mu \mathrm{L})$ were added, and samples were incubated for $30 \mathrm{~min}$ at $37^{\circ} \mathrm{C}$. Transcription was started by adding $2 \mu \mathrm{L}$ NTP mix ( $1 \mathrm{mM}$ each NTP; f.c. $200 \mu \mathrm{M}$ each) or $2 \mu \mathrm{L} \mathrm{ddH}_{2} \mathrm{O}$ instead (negative control); the f.c. of $\sigma^{\mathrm{A}}$-RNAP was $\sim 2 \mu \mathrm{M}$ and that of 6S-2 RNA $1 \mu \mathrm{M}$. Samples were then loaded onto a 7.5\% nondenaturing PAA gel $(1 \times$ TBE) as described above.

\section{Transcription of ${ }^{32} \mathrm{P}$-labeled pRNAs using 6S-1 or 6S-2 RNA as template}

Four microliters 6S RNA $(2.5 \mu \mathrm{M}$; or other concentration if indicated) that had been subjected to the folding and annealing procedure, either alone or in the presence of a synthetic pRNA oligonucleotide 
( 25 or $50 \mu \mathrm{M}$ ), were mixed with $2 \mu \mathrm{L} 5 \times$ activity buffer (supplemented with $0.5 \mu \mathrm{g} / \mu \mathrm{L}$ heparin), $1.5 \mu \mathrm{L} \mathrm{ddH}_{2} \mathrm{O}$, and $0.5 \mu \mathrm{L} \sigma^{\mathrm{A}}$ RNAP holoenzyme $(8 \mu \mathrm{g} / \mu \mathrm{L})$, followed by incubation for $30 \mathrm{~min}$ at $37^{\circ} \mathrm{C}$ to promote $6 \mathrm{~S}$ RNA:RNAP complex formation. Then, 2 $\mu \mathrm{L}$ of NTP mix (1 mM each) containing $\alpha-\left[{ }^{32} \mathrm{P}\right]$-UTP or $\alpha-\left[{ }^{32} \mathrm{P}\right]-$ ATP ( 50,000 Cherenkov c.p.m.) were added to give a final volume of $10 \mu \mathrm{L}$, followed by incubation for $30 \mathrm{~min}$ at $37^{\circ} \mathrm{C}$. Samples were mixed with two volumes of a highly denaturing RNA loading buffer $(0.02 \%[\mathrm{w} / \mathrm{v}$ ] bromophenol blue, $0.02 \%$ [w/v] xylene cyanol blue, 8 $\mathrm{M}$ urea, 50\% [v/v] deionized formamide, $2 \times \mathrm{TBE}, \mathrm{pH} 8.0)$ and loaded onto a $25 \%$ denaturing PAA gel $(1 \times \mathrm{TBE})$.

\section{S-1 and 6S-2 RNA-templated pRNA synthesis at varying NTP concentrations}

Two microliters $6 \mathrm{~S}-1$ or $6 \mathrm{~S}-2$ RNA $(5 \mu \mathrm{M})$ in $1 \times$ TE buffer were heated to $80^{\circ} \mathrm{C}$ and cooled down to $50^{\circ} \mathrm{C}$ in steps of $10^{\circ} \mathrm{C}(2 \mathrm{~min}$ each step), with a final incubation step at $37^{\circ} \mathrm{C}$ for $2 \mathrm{~min}$. Then, $4.6 \mu \mathrm{L}$ mix containing activity buffer and $\sigma^{\mathrm{A}}$-RNAP were added, followed by incubation for $10 \mathrm{~min}$ at $37^{\circ} \mathrm{C}$. Reactions were started by adding 3.4 $\mu \mathrm{L}$ NTP mix (f.c. of each NTP: 20 , 50, or $200 \mu \mathrm{M}$; including 250,000 Cherenkov c.p.m. of $\alpha-\left[{ }^{32} \mathrm{P}\right]$-UTP per gel lane). The final reaction volume of $10 \mu \mathrm{L}$ contained $1 \mu \mathrm{M}$ 6S RNA, $1 \mu \mathrm{M}$ RNAP, and $1 \times$ activity buffer (see above). After $1 \mathrm{~h}$ at $37^{\circ} \mathrm{C}$, half of each sample was mixed with $15 \mu \mathrm{L}$ of highly denaturing RNA loading buffer (see above) and analyzed by $25 \%$ denaturing PAGE $(1 \times \mathrm{TBE})$. Before gel loading, samples were heated to $98^{\circ} \mathrm{C}$ for 3 min, followed by cooling on ice for $20 \mathrm{~min}$.

\section{Prediction of 6S-1 and 6S-2 RNA structures from Bacilli}

6S RNA sequences listed for the phylum Firmicutes were taken from the RFAM database (Burge et al. 2012) and aligned to the 6S/SsrS RNA covariance model provided there. The alignment was clustered using the neighbor-joining algorithm implemented in ClustalW (Larkin et al. 2007). Thus, a similarity tree was built that grouped similar sequences (in terms of the RFAM SsrS RNA covariance model). 6S-1 and 6S-2 RNA from B. subtilis subsp. subtilis str. 168 were observed to be positioned in two separate, dense clusters of the tree. Thus, other 6S RNAs found in one of the two clusters were assumed to represent genus-typical $6 \mathrm{~S}-1$ or $6 \mathrm{~S}-2$ RNAs as well. The clusters contained 59 sequences for $6 \mathrm{~S}-1$ and 60 sequences for 6S-2 RNA. We then solely picked sequences from those species that had a 6S RNA copy in the 6S-1 as well as in the 6S-2 RNA cluster, which was the case for 28 bacterial strains (see Supplemental Material). Redundant identical sequences were removed, leaving 14 out of 28 sequences for $6 \mathrm{~S}-1$ RNA and 16 out of 28 for $6 \mathrm{~S}-2$ RNA. We realigned both groups with respect to their secondary structure using mlocarna (Will et al. 2007), which simultaneously aligns the RNAs based on sequence and structure in order to improve the meaningfulness of the alignment. Finally, RNAalifold (Hofacker et al. 2002; Bernhart et al. 2008) was applied to gain the structure with the best fit to all sequences of the alignment. Regarding the candidates chosen, we have ample evidence for their classification: (1) They form a distinct cluster with the reference 6S1 or 6S-2 RNA from B. subtilis; and (2) all species have one 6S RNA homolog that falls into the $6 \mathrm{~S}-1$ and another one that falls into the 6S-2 RNA cluster. Thus, similar biological functions for these $6 \mathrm{~S}-1 / 2$
RNAs can be assumed. The mlocarna alignment of the $146 \mathrm{~S}-1$ and 16 6S-2 RNA sequences is shown in Supplemental Figure S1.

\section{Analysis of 6S-2 RNA displacement from RNAP in the absence of NTPs}

In this experiment, $\sigma^{\mathrm{A}}$-RNAP was pre-incubated with a fivefold molar excess of radiolabeled 6S-2 RNA, followed by addition of a 10fold molar excess of 6S-1 RNA over 6S-2 RNA and varying times of incubation. 6S-2 RNA:RNAP complexes were then analyzed by native PAGE (in $1 \times$ TBE buffer). In practice, to each of seven reaction tubes, $2 \mu \mathrm{L}$ of $5 \times$ activity buffer, $1 \mu \mathrm{L}$ heparin $(400 \mathrm{ng} / \mu \mathrm{L}$; f.c. 40 $\mathrm{ng} / \mu \mathrm{L}$ ), $12.5 \mathrm{pmol}$ unlabeled 6S-2 RNA (f.c. $1.25 \mu \mathrm{M}$ ), trace amounts of radiolabeled 6S-2 RNA ( 10,000 Cherenkov c.p.m.), and $\mathrm{ddH}_{2} \mathrm{O}$ (to $8.1 \mu \mathrm{L}$ ) were added; all tubes were put at $37^{\circ} \mathrm{C}$. Immediately, $1.3 \mu \mathrm{L}$ B. subtilis $\sigma^{\mathrm{A}}$-RNAP holoenzyme $(0.8 \mu \mathrm{g} / \mu \mathrm{L}$; f.c. $\sim 0.25 \mu \mathrm{M}$ ) was added to tube $\# 6$, while $1.3 \mu \mathrm{L} \sigma^{\mathrm{A}}$-RNAP storage buffer were added to tube \#7, followed by incubation for $15 \mathrm{~min}$ at $37^{\circ} \mathrm{C}$. Then, $0.55 \mu \mathrm{L} 6 \mathrm{~S}-1$ RNA $(231 \mu \mathrm{M})$ (f.c. $\left.12.5 \mu \mathrm{M}\right)$ was added to tubes \#6 and \#7 (time point zero) to reach final volumes of $10 \mu \mathrm{L}$, followed by incubation for $120 \mathrm{~min}$ at $37^{\circ} \mathrm{C}$ (Fig. 10A, lanes 6 and 7). After $45 \mathrm{~min}$ (relative to the time point zero just mentioned), components were added in the same order (as for tube \#6) to tube \#5 (addition of RNAP, $15 \mathrm{~min}$ at $37^{\circ} \mathrm{C}$, then addition of $6 \mathrm{~S}-1$ RNA and incubation for $60 \mathrm{~min}$ at $37^{\circ} \mathrm{C}$ ). After 75, 95, and 100 min, respectively, the same was done for tubes \#2-4 (addition of RNAP, 15 min at $37^{\circ} \mathrm{C}$, then addition of $6 \mathrm{~S}-1$ RNA and incubation with 6S-1 RNA for 30, 10, or $5 \mathrm{~min}$, respectively). After $105 \mathrm{~min}, 1.3$ $\mu \mathrm{L}$ B. subtilis $\sigma^{\mathrm{A}}$-RNAP were added to tube \#1, and the mixture was incubated for $15 \mathrm{~min}$ at $37^{\circ} \mathrm{C}$, followed by addition of $0.55 \mu \mathrm{L}$ $\mathrm{ddH}_{2} \mathrm{O}$ instead of 6S-1 RNA. Then, all samples were instantly mixed with $10 \mu \mathrm{L}$ of $2 \times$ native RNA loading buffer and loaded onto a $7.5 \%$ native PAA gel $(1 \times \mathrm{TBE})$.

\section{Analysis of 6S-2 RNA displacement from RNAP in the presence of ATP and GTP}

In this type of experiment, the staggered incubation procedure was identical to that in the absence of NTPs (see above) to the point of 6S-1 RNA addition, after which samples were incubated for another $15 \mathrm{~min}$ at $37^{\circ} \mathrm{C}$. Then, ATP and GTP were added to final concentrations of $200 \mu \mathrm{M}$ each (Fig. 10B, lanes 13-17), and samples were incubated for $5,10,30,60$, or $120 \mathrm{~min}$ at $37^{\circ} \mathrm{C}$ before gel loading. The sample in lane 12 of Figure $10 \mathrm{~B}$ (time $0^{\prime}$ ) was the last to receive RNAP $30 \mathrm{~min}$ before gel loading, followed by incubation for 15 min at $37^{\circ} \mathrm{C}$, addition of $6 \mathrm{~S}-1 \mathrm{RNA}$, another incubation for 15 min at $37^{\circ} \mathrm{C}$, and addition of $\mathrm{ddH}_{2} \mathrm{O}$ instead of ATP/GTP immediately before gel loading.

\section{SUPPLEMENTAL MATERIAL}

Supplemental material is available for this article.

\section{ACKNOWLEDGMENTS}

We thank Dominik Helmecke for excellent technical assistance. This work was supported by the Deutsche Forschungsgemeinschaft (GK 1384) to P.G.H., K.D., M.L., and R.K.H., the Russian Foundation for 
Basic Research (11-04-91337) to O.Y.B., E.A.K., and T.S.O., and the Spanish Ministry of Economy and Competitiveness (BFU201123645) to M.S.

Received August 20, 2013; accepted November 22, 2013.

\section{REFERENCES}

Ando Y, Asari S, Suzuma S, Yamane K, Nakamura K. 2002. Expression of a small RNA, BS203 RNA, from the yocI-yocJ intergenic region of Bacillus subtilis genome. FEMS Microbiol Lett 207: 29-33.

Anthony LC, Artsimovich I, Svetlov V, Landic R, Burgess RR. 2000. Rapid purification of His(6)-tagged Bacillus subtilis core RNA polymerase. Protein Expr Purif 19: 350-354.

Barrick JE, Sudarsan N, Weinberg Z, Ruzzo WL, Breaker RR. 2005. 6S RNA is a widespread regulator of eubacterial RNA polymerase that resembles an open promoter. RNA 11: 774-784.

Beckmann BM, Burenina OY, Hoch PG, Sharma CM, Kubareva EA, Hartmann RK. 2011. In vivo and in vitro analysis of 6S RNA-templated short transcripts in Bacillus subtilis. RNA Biol 8: 839-849.

Beckmann BM, Hoch PG, Marz M, Willkomm DK, Salas M, Hartmann RK. 2012. A pRNA-induced structural rearrangement triggers 6S-1 RNA release from RNA polymerase in Bacillus subtilis. EMBO J 31: 1727-1738.

Bennett BD, Kimball EH, Gao M, Osterhout R, Van Dien SJ, Rabinowitz JD. 2009. Absolute metabolite concentrations and implied enzyme active site occupancy in Escherichia coli. Nat Chem Biol 5: 593-599.

Bernhart SH, Tafer H, Mückstein U, Flamm C, Stadler PF, Hofacker IL. 2006. Partition function and base pairing probabilities of RNA heterodimers. Algorithms Mol Biol 1: 3 .

Bernhart SH, Hofacker IL, Will S, Gruber AR, Stadler PF. 2008. RNAalifold: Improved consensus structure prediction for RNA alignments. BMC Bioinformatics 9: 474.

Burge SW, Daub J, Eberhardt R, Tate J, Barquist L, Nawrocki EP, Eddy SR, Gardner PP, Bateman A. 2012. Rfam 11.0: 10 years of RNA families. Nucleic Acids Res 41: D226-D232.

Cabrera-Ostertag IJ, Cavanagh AT, Wassarman KM. 2013. Initiating nucleotide identity determines efficiency of RNA synthesis from $6 \mathrm{~S}$ RNA templates in Bacillus subtilis but not Escherichia coli. Nucleic Acids Res 41: 7501-7511.

Cavanagh AT, Klocko AD, Liu X, Wassarman KM. 2008. Promoter specificity for $6 \mathrm{~S}$ RNA regulation of transcription is determined by core promoter sequences and competition for region 4.2 of $\sigma^{70}$. Mol Microbiol 67: 1242-1256.

Cavanagh AT, Sperger JM, Wassarman KM. 2012. Regulation of 6S RNA by pRNA synthesis is required for efficient recovery from stationary phase in E. coli and B. subtilis. Nucleic Acids Res 40: 2234-2246.
Fukushima T, Ishikawa S, Yamamoto H, Ogasawara N, Sekiguchi J. 2003. Transcriptional, functional and cytochemical analyses of the veg gene in Bacillus subtilis. J Biochem 133: 475-483.

Gildehaus N, Neusser T, Wurm R, Wagner R. 2007. Studies on the function of the riboregulator 6S RNA from E. coli: RNA polymerase binding, inhibition of in vitro transcription and synthesis of RNAdirected de novo transcripts. Nucleic Acids Res 35: 1885-1896.

Hofacker IL, Fekete M, Stadler PF. 2002. Secondary structure prediction for aligned RNA sequences. J Mol Biol 319: 1059-1066.

Irnov I, Sharma CM, Vogel J, Winkler WC. 2010. Identification of regulatory RNAs in Bacillus subtilis. Nucleic Acids Res 38: 6637-6651.

Larkin MA, Blackshields G, Brown NP, Chenna R, McGettigan PA, McWilliam H, Valentin F, Wallace IM, Wilm A, Lopez R, et al. 2007. Clustal W and Clustal X version 2. Bioinformatics 23: 29472948.

Lopez JM, Marks CL, Freese E. 1979. The decrease of guanine nucleotides initiates sporulation of Bacillus subtilis. Biochim Biophys Acta 587: 238-252.

Meyer FM, Jules M, Mehne FM, Le Coq D, Landmann JJ, Görke B, Aymerich S, Stülke J. 2011. Malate-mediated carbon catabolite repression in Bacillus subtilis involves the HPrK/CcpA pathway. $J$ Bacteriol 193: 6939-6949.

Neusser T, Polen T, Geissen R, Wagner R. 2010. Depletion of the noncoding regulatory $6 \mathrm{~S}$ RNA in $E$. coli causes a surprising reduction in the expression of the translation machinery. BMC Genomics 11: 165.

Ratnayake-Lecamwasam M, Serror P, Wong KW, Sonenshein AL. 2001. Bacillus subtilis CodY represses early-stationary-phase genes by sensing GTP levels. Genes Dev 15: 1093-1103.

Sogo JM, Inciarte MR, Corral J, Viñuela E, Salas M. 1979. RNA polymerase binding sites and transcription map of the DNA of Bacillus subtilis phage Ф29. J Mol Biol 127: 411-436.

Suzuma S, Asari S, Bunai K, Yoshino K, Ando Y, Kakeshita H, Fujita M, Nakamura K, Yamane K. 2002. Identification and characterization of novel small RNAs in the aspS-yrvM intergenic region of the Bacillus subtilis genome. Microbiology 148: 2591-2598.

Trotochaud AE, Wassarman KM. 2005. A highly conserved 6S RNA structure is required for regulation of transcription. Nat Struct Mol Biol 12: 313-319.

Wassarman KM. 2007.6S RNA: A small RNA regulator of transcription. Curr Opin Microbiol 10: 164-168.

Wassarman KM, Saecker RM. 2006. Synthesis-mediated release of a small RNA inhibitor of RNA polymerase. Science 314: 1601-1603.

Wassarman KM, Storz G. 2000. 6S RNA regulates E. coli RNA polymerase activity. Cell 101: 613-623.

Will S, Reiche K, Hofacker IL, Stadler PF, Backofen R. 2007. Inferring non-coding RNA families and classes by means of genome-scale structure-based clustering. PLoS Comput Biol 3: e65.

Willkomm DK, Hartmann RK. 2005. 6S RNA-an ancient regulator of bacterial RNA polymerase rediscovered. Biol Chem 386: 12731277. 

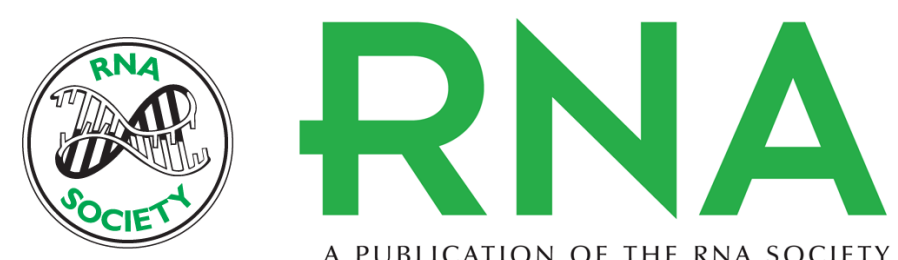

A PUBLICATION OF THE RNA SOCIETY

\section{Mechanistic comparison of Bacillus subtilis 6S-1 and 6S-2 RNAs- commonalities and differences}

Olga Y. Burenina, Philipp G. Hoch, Katrin Damm, et al.

RNA 2014 20: 348-359 originally published online January 24, 2014

Access the most recent version at doi:10.1261/rna.042077.113

\section{Supplemental http://rnajournal.cshlp.org/content/suppl/2014/01/15/rna.042077.113.DC1 Material}

References This article cites 29 articles, 5 of which can be accessed free at: http://rnajournal.cshlp.org/content/20/3/348.full.html\#ref-list-1

Creative This article is distributed exclusively by the RNA Society for the first 12 months after the Commons License full-issue publication date (see http://rnajournal.cshlp.org/site/misc/terms.xhtml). After 12 months, it is available under a Creative Commons License (Attribution-NonCommercial 3.0 Unported), as described at http://creativecommons.org/licenses/by-nc/3.0/. Email Alerting $\begin{aligned} & \text { Receive free email alerts when new articles cite this article - sign up in the box at the } \\ & \text { Service }\end{aligned}$ top right corner of the article or click here. 